\title{
A review on the electrochemical production of chlorine dioxide from chlorates and hydrogen peroxide
}

\author{
Mayra Kerolly Sales Monteiro ${ }^{1,2}$, Mayara Maria Sales Monteiro ${ }^{3}$, André Miller de Melo Henrique ${ }^{1}$, Javier \\ Llanos $^{2}$, Cristina Saez ${ }^{2}$, Elisama Vieira Dos Santos ${ }^{1,}$, Carlos Alberto Martinez-Huitle ${ }^{1}$, Manuel Andrés \\ Rodrigo $^{2}$ \\ 1- Universidade Federal do Rio Grande do Norte/UFRN, 59.078-970, Natal, RN, Brasil. \\ 2- Department of Chemical Engineering. Faculty of Chemical Sciences \& Technologies. University of Castilla La Mancha. \\ Campus Universitario s/n. 13071 Ciudad Real. Spain \\ 3- Universidade Potiguar/UnP, 59.056-000, Natal, RN, Brasil
}

\section{Abstract}

Chlorine dioxide is one of the most interesting oxidants because it combines a strong capacity of oxidation with low formation of hazardous byproducts such as chlorinated organics during its application. Because of that, it is widely used in disinfection of drinking water and, currently, it is aimed to be used in the disinfection of COVID19 from surfaces and buildings. Although it is usually produced by the chemical interaction of chlorite with hypochlorite/chlorine or hydrochloric acid, one interesting alternative for its production is the combination in strongly acidic media of chlorate and hydrogen peroxide. Both compounds are known to be efficiently manufactured with electrochemical technology, opening the possibility of a complete electrochemical process to produce this important oxidant. This review summarizes the recent progress in the electrochemical production of the two raw materials, as well as the complete electrochemical production of chlorine dioxide, not only paying attention to the scientific literature but, most importantly, to recent patents, trying to see in which TRL are each of the technologies and what are the elements of the value chain required for a complete implementation of the technology.

\section{Keywords}

Electrochemical production; chlorate; hydrogen peroxide; chlorine dioxide 


\section{Highlights}

- Chlorine dioxide can be efficiently produced from hydrogen peroxide and chlorate in acidic media

- Hydrogen peroxide production can be improved operating at high pressure and with special cell design

- Cathode has a primary influence on the production of hydrogen peroxide

- In situ electrochemical production of chlorine dioxide is feasible

- Low TRL of hydrogen peroxide production becomes the bottleneck of the electrochemical production of chlorine dioxide

*author to whom all correspondence should be addressed: Elisama Vieira elisamavieira@ect.ufrn.br) 


\section{Introduction}

Production of oxidants is a topic of the major interest for our Society. They are used in many different applications, ranging from their use as reagents in the production of many chemicals to the removal of hazardous anthropogenic pollutants contained in industrial wastes, or to the disinfection of water, where they can be used to remove not only pathogenic bacteria but also other hazardous species like viruses or fungi.

Although several important oxidants are produced using chemical technologies (e.g. hydrogen peroxide is mostly produced by the anthraquinone method), the electrochemical technology has demonstrated to be the most interesting for the production of a wide range of powerful and useful oxidants. Thus, chlorine, which is the most important oxidant nowadays, not only in the industry but also in disinfection, is produced by the very well-known chloralkaline process, in which the development of mixed metal oxides (MMO) anodes in the late sixties of the twentieth century was a real turning point. Their robustness, and the promotion in the oxidation of chlorides to chlorine with respect to the competing oxygen evolution side reaction, have allowed to obtain really high current efficiencies[1]. Several decades later of the development of MMO electrodes, other interesting electrode materials, in special the boron-doped diamond coatings, demonstrated their ability to produce efficiently many other interesting oxidants[2]. Thus, species, which were difficult to be produced up to that moment by chemical or electrochemical methods, were started to be successfully manufactured and, nowadays, the good results obtained are motivating that many of them are undergoing important research effort in order to enlarge their technology readiness level (TRL) up to levels in which the full value-chain could be completed, approaching fast to their potential commercialization.

The most important family of oxidants produced with the diamond coating electrodes are the peroxospecies[3], characterized by the presence of the functional group -O-O- and which includes peroxosulfates[4], peroxophosphates[5], peroxocarbonates[6] and peroxoacetates[7]. In addition, these new powerful electrodes can promote the oxidation of chloride, not only to chlorine but also to chlorates and perchlorate[8]. These later species, from the thermodynamic point of view, are very powerful oxidants, although their action is very limited at room temperature because of kinetic considerations and it is only promoted when the temperature is raised, where they may have important uses as explosives. Other important oxidants that are produced with these new electrodes includes perbromates[9] and ferrates[10], which are extremely difficult to be produced 
with other electrochemical technologies. Also, it is worth to highlight ozone, which can be generated efficiency, especially using special cell designs, being very efficient the use of PEM electrolyzers for its production, according to recent studies [11].

Anyway, chlorine remains as the star of the oxidants and chloralkaline industry has nowadays a huge importance. However, because of the important chemistry with organics, chlorine has many drawbacks related to the impact on environment and health, and the development of efficient processes for the production other oxidants is a real necessity $[12,13]$. This becomes an acute problem, because very few alternatives appear as realistic for the disinfection of water. Among them, chlorine dioxide emerges as the most promising[14], although sometimes its use is overvalued and, even in the present COVID19 pandemic, it has been proposed not only its efficient application as a solution for killing the virus on surfaces or in air, but also its use as medicine which, in addition to be very dangerous for human health, it has no scientific sense. Also, the formation of chlorite can become a serious drawback, although it can be managed easily according to the existing experience. Thus, chlorine dioxide is known to be one of the most important disinfectants, very appreciated in Water Treatment Facilities (WTF) because it avoids the formation of organochlorinated species[15]. Typically, in WTFs, is made on site, by combination of chlorite and hypochlorite/chlorine or hydrochloric acid[16-18]. However, alternatively, it can be rendered by reaction of chlorate with methanol, sulfur dioxide or hydrogen peroxide. Here, is where a niche of opportunity appears for electrochemical technology because the anodic transformation of chloride to chlorate is a well-known process, as well as the cathodic production of hydrogen peroxide from oxygen.

This review focuses on the production of chloride dioxide from this two precursors, shedding light on the recent knowledge about the production of each of the two reagents and their combination, by summarizing the expertise published or patented in the last five years. This information will be discussed at the light of the technology readiness level, to point out how far is the technology for the full-scale applicability.

\section{Electrochemical production of sodium chlorate.}

Chlorate is currently considered as a commodity, and it is produced industrially by electrochemical oxidation of concentrated brines of sodium chloride (over $300 \mathrm{~g} \mathrm{dm}^{-3}$ ) at high temperatures (over $60^{\circ} \mathrm{C}$ ) and acidic $\mathrm{pHs}$ in non-divided cells, with efficiencies that are over $90 \%$ when dichromate is added in the feeding brine 
formulation. Technology is fully optimized and cell voltages in the nearness of $3.0 \mathrm{~V}$, and current densities in the range $1500-4000 \mathrm{~A} \mathrm{~m}^{-2}$, are applied with specific energy consumptions near $5 \mathrm{kWh}$ per $\mathrm{kg}$ of chlorate produced. Industrial facilities do not only consist of the electrochemical cells but they also have a preelectrochemical treatment consisting of brine purification to remove different impurities contained in the sodium chloride raw material (fluoride, sulfates, calcium, ...) and a post-electrochemical treatment consisting of the surplus hypochlorite removal (using heat and hydrogen peroxide), crystallization of the chlorate, centrifugation and drying. The electrochemical cell can integrate or, alternatively, should be connected to a chemical reactor, where the slow chemical chlorate formation takes place. Cooling is necessary to regulate temperature because of the important amounts of heat dissipated. Reaction system is rather complex, consisting of a sequence of several electrolytic and chemical processes. The first stage is the oxidation of chloride to chlorine (eq 1) which competes with the oxidation of water to form oxygen (eq 2). Although historically different types of anodes were used for this process, since the last quarter of the past century use of suitable formulations of mixed metal oxides have demonstrated to be the key to allow a promotion of the first reaction, reaching outstanding efficiencies. On the cathode, the main reaction is the reduction of water to form hydrogen and hydroxyl ions (eq 3). These ions promote the disproportionation of chlorine to chloride and hypochlorite (eq 4), which later continued with further disproportionation reactions up to the formation of chlorate (eq 5). Alternatively, the electrochemical oxidation of hypochlorite to chlorate is also feasible (eq 6), being promoted with anodes such as the diamond coatings which, in turn, do not stop oxidizing in this point but also can continue up to the formation of perchlorates (eq 7). Role of hydroxyl radicals in these two later processes seems to be very important according to recent studies [19].

$$
\begin{gathered}
2 \mathrm{Cl}^{-} \rightarrow \mathrm{Cl}_{2}(a q)+2 e^{-}(1) \\
2 \mathrm{H}_{2} \mathrm{O} \rightarrow \mathrm{O}_{2}(a q)+4 \mathrm{H}^{+}+4 e^{-}(2) \\
2 \mathrm{H}_{2} \mathrm{O}+2 e^{-} \rightarrow \mathrm{H}_{2}+2 \mathrm{OH}^{-}(3) \\
\mathrm{Cl}_{2}+2 \mathrm{OH}^{-} \rightarrow \mathrm{ClO}^{-}+\mathrm{Cl}^{-}+\mathrm{H}_{2} \mathrm{O}(4) \\
3 \mathrm{ClO}^{-} \leftrightarrows \mathrm{ClO}_{3}^{-}+2 \mathrm{Cl}^{-}(5) \\
6 \mathrm{HOCl}+3 \mathrm{H}_{2} \mathrm{O} \rightarrow 2 \mathrm{ClO}_{3}^{-}+4 \mathrm{Cl}^{-}+12 \mathrm{H}^{+}+3 / 2 \mathrm{O}_{2}(\mathrm{aq})+6 \mathrm{e}^{-}(6) \\
2 \mathrm{ClO}_{3}-+\mathrm{H}_{2} \mathrm{O} \rightarrow 2 \mathrm{ClO}_{4}^{-}+2 \mathrm{H}^{+}+2 \mathrm{e}^{-}(7)
\end{gathered}
$$


Table 1 shows some of the recent progress regarding this process. It is important to consider that most of them are related to fundamental studies at very low TRL, trying to develop new electrodic materials, avoid or promote the formation of perchlorate or, simply, to elucidate the role of dichromate on the efficient production of chlorates. Also, to prevent the formation of chlorates during the treatment of water or wastewater containing chlorides, which has been found to be a major problem for a safe supply of disinfected water or for a proper reclaiming of wastewater. Evaluation of the production of chlorates with anodes consisting of diamond coatings has also been a very important point of concern, and comparisons of the performance of these novel electrodes with different formulations of metal mixed oxides (MMO) has attracted the interest of researchers. However, although this new electrode has demonstrated a much higher oxidation capacity, production of perchlorates has been found as a major drawback and MMO still remains as the reference electrode to produce chlorates.

Table 1. Recent works related to chlorate production

\begin{tabular}{|c|c|c|c|}
\hline $\begin{array}{c}\text { Objective / Technology } \\
\text { evaluated }\end{array}$ & $\begin{array}{l}\text { Electrolyte composition / } \\
\text { electrode type /operation } \\
\text { conditions }\end{array}$ & Main conclusions drawn & Ref. \\
\hline 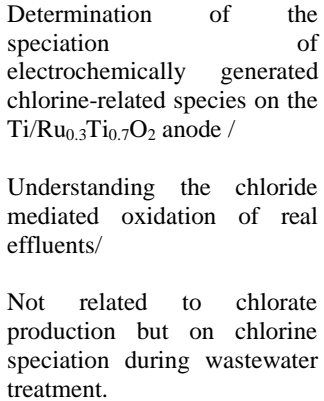 & $\begin{array}{l}\text { Aqueous solution containing } \\
\mathrm{NaCl}\left(1.25 \mathrm{~g} \mathrm{~L}^{-1}\right) / \\
\mathrm{Ti} / \mathrm{Ru}_{0.3} \mathrm{Ti}_{0.7} \mathrm{O}_{2} \text { anode/ } \\
\text { Current densities ranging from } \\
25 \text { to } 75 \mathrm{~mA} \mathrm{~cm}{ }^{-2}\end{array}$ & $\begin{array}{l}\text { Oxygen evolution inhibition } \\
\text { depends predominantly on the } \\
\text { specific electrochemical } \\
\text { species formed }\left(\mathrm{Cl}_{2}, \mathrm{HClO} \text {, }\right. \\
\mathrm{ClO}^{-} \text {, chlorite, chlorine } \\
\text { dioxide). } \\
\text { The elimination of organic } \\
\text { matter was achieved ranging } \\
\text { from } 80 \% \text { to } 86 \% \text {. }\end{array}$ & [20] \\
\hline $\begin{array}{l}\text { Elucidation of the mechanisms } \\
\text { of perchlorate }\left(\mathrm{ClO}_{4}^{-}\right) \\
\text {formation from chlorate }\left(\mathrm{ClO}_{3}-\right. \\
\text { ) on boron-doped diamond } \\
\text { (BDD) film anodes by use of a } \\
\text { rotating disk electrode reactor. }\end{array}$ & $\begin{array}{l}\text { Reaction rates for } \mathrm{ClO}_{3}^{-} \\
\text {removal and } \mathrm{ClO}_{4}^{-} \text {formation } \\
\text { were measured at constant } \\
\text { potential conditions by use of a } \\
\text { rotating disk electrode (RDE) } \\
\text { experimental setup } \\
\text { Ultrananocrystalline BDD } \\
\text { films p-silicon substrates/ } \\
\text { Rates of } \mathrm{ClO}_{4}^{-} \text {formation were } \\
\text { determined as functions of the } \\
\text { electrode potential }(2.29-2.70 \\
\mathrm{V} / \quad \text { standard hydrogen } \\
\text { electrode, SHE) and } \\
\text { temperature }\left(10-40{ }^{\circ} \mathrm{C}\right) \text {. }\end{array}$ & $\begin{array}{l}\text { Combination of direct electron } \\
\text { transfer and hydroxyl radical } \\
\text { oxidation with a measured } \\
\text { apparent activation energy of } \\
6.9 \pm 1.8 \mathrm{~kJ} \mathrm{~mol}^{-1} \text { at a potential } \\
\text { of } 2.60 \mathrm{~V} / \mathrm{SHE} / \\
\mathrm{ClO}_{4}^{-} \text {production rates were } \\
\text { zero order with respect to } \mathrm{ClO}_{3}^{-} \\
\text {concentration. }\end{array}$ & {$[21]$} \\
\hline
\end{tabular}




\begin{tabular}{|c|c|c|c|}
\hline $\begin{array}{l}\text { The electrochemical } \\
\text { generation of several oxidative } \\
\text { species was studied at the } \\
\text { surfaces of five commercial } \\
\text { boron-doped diamond anodes } \\
\text { with different doping levels } \\
(100-8000 \mathrm{ppm}) / \\
\text { All materials evaluated were } \\
\text { characterized by linear sweep } \\
\text { voltammetry, cyclic } \\
\text { voltammetry, electrochemical } \\
\text { impedance spectroscopy, } \\
\text { contact angle, and scanning } \\
\text { electron microscopy, as well as } \\
\text { by bulk electrolysis/ }\end{array}$ & $\begin{array}{l}\text { The electrolyte solution was } \\
\text { prepared by } 3.0 \mathrm{~g} \mathrm{~L}^{-1} \mathrm{Na}_{2} \mathrm{SO}_{4} \\
\text { or } 3.7 \mathrm{~g} \mathrm{~L}^{-1} \text { of } \mathrm{NaCl} \text { and } \mathrm{H}_{2} \mathrm{SO}_{4} \\
0.5 \mathrm{~mol} \mathrm{~L}^{-1} / \\
\text { BDD anodes/ } \\
\mathrm{CV} \mathrm{measurements} \mathrm{were} \\
\text { performed at the potential } \\
\text { limits of }-0.7-+1.1 \mathrm{~V}^{-1} \text { ith a } \\
\text { scan rate of } 100 \mathrm{mV} \mathrm{s}^{-1} \text { in a } \\
\text { solution of }\left[\mathrm{Fe}(\mathrm{CN})_{6}\right]^{3-}-4^{-4} 0.01 \\
\text { mol L in } 0.1 \text { mol L } \mathrm{L}^{-1} \mathrm{Na}_{2} \mathrm{SO}_{4} \text {. } \\
\text { Linear sweep voltammetry } \\
\text { experiments were performed in } \\
\text { the potential interval of } 0.0- \\
2.7 \mathrm{~V} \text {. }\end{array}$ & $\begin{array}{l}\text { Low boron doping favors the } \\
\text { formation of hydroxyl radicals, } \\
\text { while higher doping levels } \\
\text { favor the direct oxidation of } \\
\text { sulfate and chloride on the } \\
\text { surface of the diamond } \\
\text { electrodes. }\end{array}$ & [22] \\
\hline $\begin{array}{l}\text { The behavior of } \mathrm{RuO}_{2} \text { and } \\
\text { DSA anodes in hypochlorite } \\
\text { oxidation is compared to } \\
\text { outline limitations of the anode } \\
\text { performance in the chlorate } \\
\text { process/ } \\
\text { Comparison of the } \\
\text { voltammetric and DEMS } \\
\text { (electrochemical mass } \\
\text { spectrometery) characteristics. }\end{array}$ & $\begin{array}{l}\text { Solution based on } 0.1 \mathrm{M} \\
\mathrm{NaClO}_{4} \text { electrolyte }(30 \mathrm{mM} \text { of } \\
\text { hypochlorite/hypochlorous } \\
\text { acid }) / \\
\text { Nanocrystalline ruthenium } \\
\text { dioxide }\left(\mathrm{RuO}_{2}\right) \text { and DSA } \\
\left(\mathrm{Ti}_{0,7} \mathrm{Ru}_{0,3} \mathrm{O}_{2}\right) \text { anodes/ } \\
\text { All experiments were carried } \\
\text { out at polarization rate of } \\
5 \mathrm{mV} / \mathrm{s} \text { in the potential range } \\
\text { between } 0.3 \text { to } 1.3 \mathrm{~V} \text { vs. } \\
\mathrm{Ag} / \mathrm{AgCl} \text {. }\end{array}$ & $\begin{array}{l}\text { The catalytic hypochlorite } \\
\text { decomposition observed for } \\
\text { DSA represents a serious } \\
\text { barrier for the chlorate process, } \\
\text { outlining the need of further } \\
\text { optimization of the industrial } \\
\text { grade anode for the chlorate } \\
\text { process. }\end{array}$ & [23] \\
\hline $\begin{array}{l}\text { Assessment of the viability of } \\
\text { the electrochemical production } \\
\text { of perchlorate from such high } \\
\text { concentration of the raw } \\
\text { materials/ } \\
\text { The valorization of brines, } \\
\text { with concentrations like those } \\
\text { produced by reverse osmosis } \\
\text { or electrodialysis processes, by } \\
\text { electrolysis with diamond } \\
\text { anodes is evaluated. }\end{array}$ & $\begin{array}{l}\text { Solutions of } \mathrm{NaCl} \text { (with target } \\
\text { concentrations ranging from } \\
1.0 \text { to } 2.0 \mathrm{M} \text { and an additional } \\
\text { test at } 5.0 \mathrm{M} \text { ) / } \\
\text { BDD was used as the anode } \\
\text { and stainless steel was used as } \\
\text { the cathode/ } \\
\text { The anolyte consisted of } \\
\text { different solutions of sodium } \\
\text { chloride with concentrations } \\
\text { ranging from } 1.0 \text { to } 5.0 \mathrm{M} \text {, and } \\
\text { the catholyte consisted of } 1.0 \\
\mathrm{M} \text { solutions of sodium } \\
\text { hydroxide. }\end{array}$ & $\begin{array}{l}\text { It is possible to transform more } \\
\text { than } 80 \% \text { of the initial chloride } \\
\text { concentration into perchlorate, } \\
\text { with current efficiencies higher } \\
\text { than } 70 \% \text {, regardless of the } \\
\text { initial concentration of sodium } \\
\text { chloride contained in the brine. }\end{array}$ & [8] \\
\hline $\begin{array}{l}\text { Provide relevant information } \\
\text { to better understand the } \\
\text { fundamental mechanisms of } \\
\text { chloride electro-chlorination } \\
\text { and oxidation processes in } \\
\text { BDD / } \\
\text { A semi-quantitative analysis of } \\
\text { various volatile species } \\
\text { produced during the } \\
\text { electrolysis of highly saline } \\
\text { water at BDD electrode has } \\
\text { been conducted by differential } \\
\text { electrochemical } \\
\text { spectrometry (DEMS) using } \\
\text { the dual thin layer flow } \\
\text { through cell. }\end{array}$ & $\begin{array}{l}\text { Sodium chloride ( } 99.9 \% \\
\text { ChemSolute) was used as main } \\
\text { component of the water matrix } \\
\text { to prepare synthetic seawater } \\
(0.6 \mathrm{M} \mathrm{NaCl}) / \\
\text { BDD working electrode/ } \\
\text { Potential step experiments } \\
\text { were conducted holding at } 0 \mathrm{~V} \\
\text { vs. Ag/AgCl in the supporting } \\
\text { electrolyte with the desired pH } \\
\text { for } 60 \mathrm{~s} \text {, then stepped to } 3 \mathrm{~V} \text { vs. } \\
\text { Ag/ } \mathrm{AgCl} \text { for } 100 \mathrm{~s} \text { (steady state } \\
\text { current transients). Afterwards, } \\
\text { the potential was stepped back } \\
\text { to } 0 \mathrm{~V} \text {. }\end{array}$ & $\begin{array}{l}\text { The quantification of released } \\
\text { species highlighted that the } \\
\text { evolution of chlorine } \\
\text { corresponds to a ca. } 80 \% \text { of the } \\
\text { current efficiency, which is a } \\
\text { significant contribution to the } \\
\text { overall electro-chlorination } \\
\text { process. }\end{array}$ & [24] \\
\hline
\end{tabular}




\begin{tabular}{|c|c|c|c|}
\hline $\begin{array}{l}\text { Influence of the electrode } \\
\text { materials and technical cells } \\
\text { for chlorate and perchlorate } \\
\text { formation potential under } \\
\text { laboratory- and technical- } \\
\text { scale conditions/ } \\
\text { Electrochemical } \\
\begin{array}{l}\text { Activation or Water } \\
\text { Electrolysis (IE). Inline }\end{array}\end{array}$ & 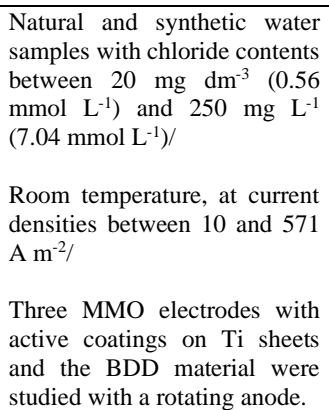 & $\begin{array}{l}\text { Only one MMO material } \\
\text { showed chlorate formation in } \\
\text { the laboratory experiments, } \\
\text { whereas in technical cells, in } \\
\text { all four cases, chlorate was } \\
\text { detected, but perchlorate was } \\
\text { not found on MMO anodes. }\end{array}$ & [25] \\
\hline $\begin{array}{l}\text { Evaluation of electrocatalytic } \\
\text { materials which can be used as } \\
\text { efficient cathode to produce } \\
\text { sodium chlorate. }\end{array}$ & $\begin{array}{l}\text { The materials consist of } \\
\text { nanocrystalline iron aluminide } \\
\text { alloys doped with catalytic } \\
\text { species such as Ru. }\end{array}$ & $\begin{array}{l}\text { Contrary to the previously } \\
\text { reported } \mathrm{Ti}_{2} \mathrm{RuFe} \text { catalytic } \\
\text { material, these new } \\
\text { electrocatalysts do not absorb } \\
\text { hydrogen and, are more stable } \\
\text { during the hydrogen evolution } \\
\text { reaction. }\end{array}$ & [26] \\
\hline $\begin{array}{l}\text { Evaluation of the role and } \\
\text { importance of chromium (VI) } \\
\text { in the chlorate manufacturing } \\
\text { process/ } \\
\text { Sodium chlorate is industrially } \\
\text { produced by electrolysis of an } \\
\text { aqueous salt solution, in which } \\
\text { chromium (VI) constitutes an } \\
\text { important excipient } \\
\text { component. }\end{array}$ & 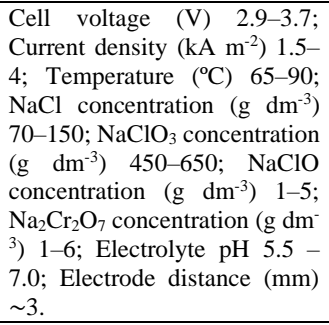 & $\begin{array}{l}\text { There is no way to efficiently } \\
\text { run chlorate electrolysis } \\
\text { without the addition of } \\
\text { chromium (VI). It is shed light } \\
\text { on the role of chromium. }\end{array}$ & [27] \\
\hline $\begin{array}{l}\text { Elucidation of the role of } \\
\text { chromate. Results were } \\
\text { validated with data from bench } \\
\text { scale and pilot plant trials. }\end{array}$ & $\begin{array}{l}\text { Trials were made in a } 500 \mathrm{~mL} \\
\text { batch reactor in the ranges } 70- \\
80{ }^{\circ} \mathrm{C}, 5.0-7.7 \quad \mathrm{~mol} / \mathrm{L} \text { ionic } \\
\text { strength, } 0-5 \mathrm{~g} / \mathrm{L} \mathrm{Na}_{2} \mathrm{Cr}_{2} \mathrm{O}_{7} \text { and } \\
\text { pH 5.8-7. }\end{array}$ & $\begin{array}{l}\text { The fraction of chlorate formed } \\
\text { by chromate catalysis depends } \\
\text { primarily on the dichromate } \\
\text { concentration but also on pH } \\
\text { and other operation } \\
\text { parameters. Under industrial } \\
\text { operation conditions, it is } \\
\text { reasonable to assume that } 30- \\
70 \% \text { of the chlorate is formed } \\
\text { by chromate catalysis. }\end{array}$ & [28] \\
\hline $\begin{array}{l}\text { Evaluation of the influence of } \\
\text { several treatments (oxidation } \\
\text { with potassium permanganate, } \\
\text { chlorine dioxide and sodium } \\
\text { hypochlorite, } \\
\text { coagulation/flocculation with } \\
\text { ferric chloride and aluminum } \\
\text { sulfate, filtration and } \\
\text { adsorption onto activated } \\
\text { carbon) on chlorine dioxide } \\
\text { consumption and on chlorite } \\
\text { and chlorate formation in the } \\
\text { final oxidation/disinfection } \\
\text { stage/ } \\
\text { Not related to electrochemistry } \\
\text { but results with great } \\
\text { applicability. }\end{array}$ & $\begin{array}{l}\text { Laboratory scale employing } \\
\text { water samples collected from } \\
\text { the DWTP of Cremona (Italy). }\end{array}$ & $\begin{array}{l}\text { The chlorine dioxide demand } \\
\text { is high when sodium } \\
\text { hypochlorite or potassium } \\
\text { permanganate are employed in } \\
\text { pre-oxidation. On the other } \\
\text { hand, chlorine dioxide leads to } \\
\text { the highest production of } \\
\text { chlorite and chlorate. }\end{array}$ & [29] \\
\hline $\begin{array}{l}\text { Photoanodic } \begin{array}{r}\text { chlorine } \\
\text { generation and chlorate }\end{array} \\
\text { formation were investigated } \\
\text { using a nanoporous } \mathrm{TiO}_{2} \\
\text { photo-electrode }\end{array}$ & $\begin{array}{l}\text { The electrochemical } \\
\text { experiments were performed } \\
\text { by biasing a } \mathrm{TiO}_{2} \text { anode with a } \\
\text { potential of } 1.0 \mathrm{~V} \text { vs. SCE with } \\
7.4 \mathrm{~mW} / \mathrm{cm}^{2} \mathrm{UV} \text { illumination. } \\
\text { A } 100 \mathrm{~mL} \text { test solution }\end{array}$ & $\begin{array}{l}\text { Chlorine formation increased } \\
\text { over time finally reaching a } \\
\text { steady-state concentration of } \\
42 \mathrm{mg} / \mathrm{L} \text { in } 45 \text { rain. On the } \\
\text { other hand, chlorate formation } \\
\text { was observed after only } 5 \mathrm{~min}\end{array}$ & [30] \\
\hline
\end{tabular}




\begin{tabular}{|c|c|c|c|}
\hline & $\begin{array}{l}\text { containing } 1.0 \times 10^{-2} \mathrm{M} \mathrm{NaCl} \\
\text { was used in each compartment. }\end{array}$ & $\begin{array}{l}\text { irradiation and increased over } \\
\text { time. }\end{array}$ & \\
\hline $\begin{array}{l}\text { The characteristics of chlorate } \\
\left(\mathrm{ClO}_{3}^{-}\right) \text {and perchlorate }\left(\mathrm{ClO}_{4}^{-}\right) \\
\text {formation were studied during } \\
\text { the electrolysis of water } \\
\text { containing chloride ions }\left(\mathrm{Cl}^{-}\right) \text {. }\end{array}$ & 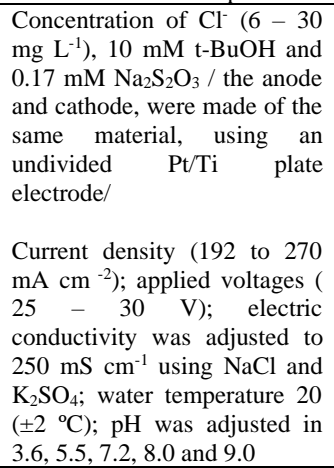 & $\begin{array}{l}\text { The direct oxidation reaction } \\
\text { rate of } \mathrm{Cl}^{-} \text {to } \mathrm{ClO}_{3}^{-} \text {was } 13 \% \text {. } \\
\text { The key formation pathways of } \\
\mathrm{ClO}_{3}^{-} \text {and } \mathrm{ClO}_{4}^{-} \text {were studied } \\
\text { using kinetic model } \\
\text { development. }\end{array}$ & [31] \\
\hline $\begin{array}{l}\text { The products of the oxidation } \\
\text { at BDD anode of chloride ions } \\
\text { in aqueous solutions were } \\
\text { identified during galvanostatic } \\
\text { electrolyses performed in a } \\
\text { filter-press reactor operating } \\
\text { both in batch and continuous } \\
\text { mode }\end{array}$ & $\begin{array}{l}\begin{array}{l}\text { Solution contained } 100 \mathrm{ppm} \text { of } \\
\text { chloride ions/ }\end{array} \\
\text { Boron doped diamond (BDD) } \\
\text { anode/ } \\
\text { Anodic current density values } \\
\text { ranging from } 2.5 \text { to } 7.6 \mathrm{~mA} \mathrm{~cm}- \\
2 / \\
\text { Solutions containing } 200 \mathrm{mg} \\
\mathrm{dm}^{-3} \text { of } \mathrm{SO}_{4}^{2-} \text { as supporting } \\
\text { electrolyte and different } \\
\text { amount of } \mathrm{Cl}^{-} \text {ranging from } 50 \\
\text { to } 2500 \mathrm{mg} \mathrm{dm}^{-3} \text {. }\end{array}$ & $\begin{array}{l}\text { Low chloride concentrations } \\
\text { electrolysis with BDD anode } \\
\text { produce a mixture of powerful } \\
\text { oxidant: low current density, } \\
\text { high mass transfer conditions } \\
\text { and low residence time were } \\
\text { found as optimal conditions to } \\
\text { maximize the concentration of } \\
\text { oxidants and minimize the } \\
\text { concentration of chlorates. }\end{array}$ & [32] \\
\hline
\end{tabular}

Anyway, it is worth to take in mind that production of chlorates is nowadays at a very high TRL. That is, the most important aspects are fully develop by process engineers in the industry for the full-scale production, which is a really-mature technology. Consequently, they are not in the primary focus on academic researchers but of researchers of private companies aiming to improve the efficiency of the processes and this type of progress is not typically disseminated but preserved in order to give a commercial advantage in the competitivity of companies.

\section{Electrochemical production of hydrogen peroxide}

Although hydrogen peroxide can be formed electrochemically on the surface of the anode by oxidation of water (eq 8), the harsh oxidation conditions generated on this surface and in its nearness leads to further oxidation of this oxidant molecule to other more oxidized species (oxygen and even ozone) and, hence, it is not considered as an efficient pathway to explain its generation.

$$
2 \mathrm{H}_{2} \mathrm{O} \rightarrow \mathrm{H}_{2} \mathrm{O}_{2}+2 \mathrm{H}^{+}+2 e^{-}(8)
$$


Alternatively, it can also be generated by decomposition of other anodically formed species, such as peroxosulfate, which can either be not only electrochemical but also chemical, specially promoted by operation at high temperatures (eq 9)

$$
\mathrm{H}_{2} \mathrm{SO}_{5}+\mathrm{H}_{2} \mathrm{O} \rightarrow \mathrm{H}_{2} \mathrm{SO}_{4}+\mathrm{H}_{2} \mathrm{O}_{2}(9)
$$

However, the reduction of oxygen on the surface of the cathode, summarized in equation 10, is known to be the key reaction involved in the production of this oxidant and this reaction competes with the further reduction of this oxidant to water (eq 11) and with the reduction of water to hydrogen (eq 12).

$$
\begin{gathered}
\mathrm{O}_{2}(\mathrm{aq})+2 \mathrm{H}^{+}+2 e^{-} \rightarrow \mathrm{H}_{2} \mathrm{O}_{2}(10) \\
\mathrm{H}_{2} \mathrm{O}_{2}+2 \mathrm{H}^{+}+2 e^{-} \rightarrow \mathrm{H}_{2} \mathrm{O}(11) \\
2 \mathrm{H}_{2} \mathrm{O}+2 e^{-} \rightarrow \mathrm{H}_{2}+2 \mathrm{OH}^{-}(12)
\end{gathered}
$$

Depending on the cathodic potential, the production of hydrogen peroxide can be promoted with respect to the formation of the other two competing species. In fact, this reaction is known to be very sensitive to many factors and in order to reach high rates for the production of hydrogen peroxide the system should include the development of 1) highly catalytic cathodic surfaces which allows the efficient transformation of oxygen into hydrogen peroxide[33], 2) pressurization to improve the solubility of oxygen and, hence, decrease mass transport limitations[34], 3) improve gas-liquid contact and minimize compression energy consumption by using jet aeration[35, 36] and 4) improve the mechanical design of the cell by using a flow-through cathode and minimize the ohmic resistance by including microfluidic strategy[36, 37]. This way, efficiencies nearly $100 \%$ can be reached. These values are very competitive but, event that, the anthraquinone method remains to be the most used nowadays and many efforts has still to be made to fill in the complete value chain of this alternative production in particular trying to obtain formulations for the cathode stable enough as to be applied industrially. Table 2 supports all these conclusions by summarizing the recent progress found in the literature regarding hydrogen peroxide production. 
Table 2. Recent works related to hydrogen peroxide production

\begin{tabular}{|c|c|c|c|}
\hline $\begin{array}{c}\text { Objective / Technology } \\
\text { evaluated }\end{array}$ & $\begin{array}{l}\text { Electrolyte composition / } \\
\text { electrode type /operation } \\
\text { conditions }\end{array}$ & Main conclusions & Ref. \\
\hline $\begin{array}{l}\text { Evaluation of electrocatalysts } \\
\text { produced from ceria high aspect } \\
\text { ratio nanostructures }\left(\mathrm{CeO}_{2}\right. \\
\mathrm{HARN} \text { ) supported on black } \\
\text { carbon (Vulcan XC-72) in } \\
\text { different mass proportions of } \\
\mathrm{CeO}_{2} \mathrm{HARN}(1 \%, 2.5 \%, 4 \% \text {, } \\
5.5 \% \text { and } 10 \%) \text { by examining } \\
\text { the oxygen reduction reaction } \\
(\mathrm{ORR}) \text { in alkaline medium (1 } \\
\left.\text { mol } \mathrm{L}^{-1} \mathrm{NaOH}\right) \text { for the electro- } \\
\text { generation of } \mathrm{H}_{2} \mathrm{O}_{2} \text {. }\end{array}$ & $\begin{array}{l}1 \mathrm{~mol} \mathrm{~L}^{-1} \mathrm{NaOH} \text { saturated with } \\
\mathrm{O}_{2} / \text { Vulcan XC-72 and Pt/C E- } \\
\mathrm{TEK} / \\
\text { The } \mathrm{CeO}_{2} \text { HARN were } \\
\text { prepared via a hydrothermal } \\
\text { method and were supported on } \\
\text { Vulcan XC-72 via an } \\
\text { impregnation method. }\end{array}$ & $\begin{array}{l}\text { The } \mathrm{CeO}_{2} \text { HARN/C-based } \\
\text { electrocatalysts is promising } \\
\text { for in situ } \mathrm{H}_{2} \mathrm{O}_{2} \text { electro- } \\
\text { generation via } \\
\text { electrochemical advanced } \\
\text { oxidation processes. } \\
\text { The catalyst containing } 1 \% \\
\mathrm{CeO}_{2} \mathrm{HARN} \text { shows more } \\
\text { promising results and } \\
\text { contains a low metallic oxide } \\
\text { load supported on the carbon, } \\
\text { increasing its cost-benefit. }\end{array}$ & [38] \\
\hline $\begin{array}{l}\text { A nitric acid modified graphite / } \\
\text { polytetrafluoroethylene (PTFE) } \\
\text { composite cathode with exterior } \\
\text { hydrophobic film was fabricated } \\
\text { for cost-effective electro- } \\
\text { generation of hydrogen peroxide } \\
\left(\mathrm{H}_{2} \mathrm{O}_{2}\right) \text {. }\end{array}$ & $\begin{array}{l}250 \mathrm{~mL} \text { of } 0.1 \mathrm{M} \mathrm{Na}_{2} \mathrm{SO}_{4} \text { and } \\
\text { flow rate of } 2.0 \mathrm{~L} \mathrm{~min}^{-1} \text { by an } \\
\text { air pump to feed } \mathrm{O}_{2} / \text { utilizing } \\
\mathrm{HNO}_{3} \text { modified } \\
\text { graphite/polytetrafluoroethyle } \\
\text { ne cathode with exterior } \\
\text { hydrophobic film/ } \\
\text { Mass graphite/PTFE binder } \\
\text { ratio }(1: 1-4: 1) ; \mathrm{pH}(3.0-9.0) \\
\text { and current density }(3.0-15 \mathrm{~mA} \\
\left.\mathrm{cm}^{-2}\right) \text {. }\end{array}$ & $\begin{array}{l}\text { With the } 2 \mathrm{M} \mathrm{HNO}_{3} \\
\text { modification rendered, } \mathrm{H}_{2} \mathrm{O}_{2} \\
\text { electro-generation was } \\
\text { improved. } \\
\text { The exterior hydrophobic } \\
\text { film on the as-prepared } \\
\text { graphite/PTFE cathode } \\
\text { endowed the cathode with } \\
\text { strong hydrophobic stability. }\end{array}$ & [39] \\
\hline $\begin{array}{l}\text { The effect of pressure on the } \\
\text { electrochemical generation of } \\
\text { hydrogen peroxide was studied } \\
\text { in undivided cells changing the } \\
\text { pressure from } 0 \text { to } 30 \text { relative bar } \\
\text { and the current density from } 1 \text { to } \\
100 \mathrm{~mA} \mathrm{~cm}-2\end{array}$ & $\begin{array}{l}50 \mathrm{mM} \mathrm{Na} \mathrm{SO}_{4} / \text { undivided } \\
\text { cells on carbon felt electrodes } \\
\text { with carbon black }+ \text { PTFE } \\
\text { mixture } \\
\text { Current densities within the } \\
\text { range } 1-100 \mathrm{~mA} \mathrm{~cm}^{-2} \text {. }\end{array}$ & $\begin{array}{l}\text { Under the best conditions }(30 \\
\text { bar and } 100 \mathrm{~mA} \mathrm{~cm} \text {-2 } \\
\text { concentrations up to } 225 \mathrm{mM} \\
\text { together with the highest } \\
\text { production rate }(1.84 \mathrm{mmol} \\
\left.\mathrm{H}_{2} \mathrm{O}_{2} \mathrm{~cm}^{-2} \mathrm{~h}^{-1} \text { and } 98.9 \% \mathrm{CE}\right) \\
\text { in an electrolytic system fed } \\
\text { with air are reported. }\end{array}$ & [34] \\
\hline $\begin{array}{l}\text { Cathode modification to support } \\
\text { efficient } \mathrm{H}_{2} \mathrm{O}_{2} \text { electro- } \\
\text { generation via the reduction of } \\
\text { dissolved anodic } \mathrm{O}_{2} \text {. Graphite } \\
\text { felt (GF) is in situ anodically } \\
\text { modified by electrode polarity } \\
\text { reversal technique in an acid- } \\
\text { free, low conductivity } \\
\text { electrolyte. }\end{array}$ & $\begin{array}{l}\mathrm{An} \text { electrolyte of } 50 \mathrm{mM} \\
\mathrm{Na}_{2} \mathrm{SO}_{4} \text { or a simulated } \\
\text { groundwater that consists of } \\
5 \mathrm{mM} \mathrm{Na}_{2} \mathrm{SO}_{4} \text { and } 0.3 \mathrm{mM} \\
\mathrm{CaSO}_{4} \text { were used. } \\
\text { For electrochemical } \\
\text { modification, the GF electrode } \\
\text { served as an anode while the } \\
\text { Ti/MMO electrode served as a } \\
\text { cathode/ } \\
\text { An undivided electrochemical } \\
\text { batch reactor was used for } \\
\mathrm{H}_{2} \mathrm{O}_{2} \text { generation and GF } \\
\text { modification. The oxygen was } \\
\text { in situ supplied by the } \\
\mathrm{Ti}^{2} / \mathrm{MMO}^{2} \text { anode because } \\
\text { oxygen supplied by external } \\
\text { pure } \mathrm{O}_{2} \text { or air aeration usually } \\
\text { achieves an extremely low } \\
\mathrm{O}_{2} / \text { air utilization efficiency }(< \\
0.1 \%) \text {. }\end{array}$ & $\begin{array}{l}\text { The modified GF exhibits a } \\
\text { significantly higher activity } \\
\text { towards } \mathrm{O}_{2} \text { reduction (up to } \\
183.3 \% \text { higher } \mathrm{H}_{2} \mathrm{O}_{2} \text { yield is } \\
\text { obtained). } \\
\text { The modified GF can } \\
\text { produce } \mathrm{H}_{2} \mathrm{O}_{2} \text { at a high yield } \\
\text { under neutral pH and low } \\
\text { current intensity by the } \\
\text { modified GF ( } 35 \% \text { of the } \\
\text { charge need to produce the } \\
\text { same amount by unmodified } \\
\text { GF). }\end{array}$ & [40] \\
\hline
\end{tabular}




\begin{tabular}{|c|c|c|c|}
\hline $\begin{array}{l}\text { Proof of concept of a new cell for } \\
\text { the in-situ electrochemical } \\
\text { production of } \mathrm{H}_{2} \mathrm{O}_{2} \text { from oxygen } \\
\text { reduction reaction }\end{array}$ & $\begin{array}{l}50 \mathrm{mM} \mathrm{Na} \mathrm{Na}_{4} / \text { In both } \\
\text { electrochemical cells, a } \\
\text { modified carbon felt (CF) } \\
\text { electrode was used as the } \\
\text { cathode/ } \\
\text { The new cell incorporates a } \\
\text { venturi-based jet aerator to } \\
\text { supply atmospheric oxygen } \\
\text { without additional energy } \\
\text { consumption to a 3D flow- } \\
\text { through modified carbon felt } \\
\text { (CF) cathode. }\end{array}$ & $\begin{array}{l}\text { Suitable design with higher } \\
\text { efficiency that a flow-by cell } \\
\text { with a gas diffusion cathode } \\
\text { under similar conditions. }\end{array}$ & $\begin{array}{l}{[35,} \\
41]\end{array}$ \\
\hline $\begin{array}{l}\text { Testing of a highly effective } \\
\text { composite acetylene black - } \\
\text { PTFE cathode consisting of a } \\
\text { sheet active core and a damp- } \\
\text { proof coating has been } \\
\text { developed. }\end{array}$ & $\begin{array}{l}\text { Air as } \mathrm{O}_{2} \text { source in } \mathrm{Na}_{2} \mathrm{SO}_{4} \\
\text { solution of } 0.05 \mathrm{M} \text {. / composite } \\
\text { acetylene black-PTFE cathode } \\
\begin{array}{l}\text { Current densities: } 12,-48 \mathrm{~mA} \\
\mathrm{~cm}^{-2} /\end{array} \\
\begin{array}{l}\text { Three - electrode undivided } \\
\text { cell }\end{array}\end{array}$ & $\begin{array}{l}\text { The cathode use not only } \mathrm{O}_{2} \\
\text { dissolved in the electrolyte } \\
\text { but also } \mathrm{O}_{2} \text { in air bubbles as } \\
\mathrm{O}_{2} \text { source for the electro- } \\
\text { generation of } \mathrm{H}_{2} \mathrm{O}_{2} \text {. }\end{array}$ & [42] \\
\hline $\begin{array}{l}\text { Preparation of a hydrophobic } \\
\text { cathode equipped with cracks for } \\
\text { gas transfer }\end{array}$ & 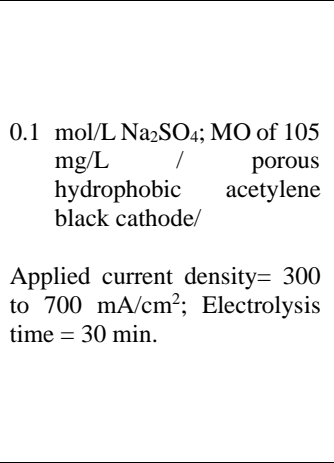 & $\begin{array}{l}\text { Cracks can avoid the } \\
\text { formation of bubbles in the } \\
\text { porous electrode which is } \\
\text { favorable to gas } \\
\text { transmission. } \\
\text { The reaction is almost not } \\
\text { affected by the content of } \\
\text { dissolved oxygen and the gas } \\
\text { flow with this structure. } \\
\text { The } \mathrm{H}_{2} \mathrm{O}_{2} \text { concentrations up } \\
\text { to } 14.4 \mathrm{mmol} / \mathrm{L} \text { after } 30 \text { min } \\
\text { electrolysis with current } \\
\text { efficiency beyond } 90 \% \text { are } \\
\text { obtained. }\end{array}$ & [43] \\
\hline $\begin{array}{l}\text { Electrosynthesis of } \\
\text { polypyrrole/multi-walled carbon } \\
\text { nanotube (MWCNT) } \\
\text { nanocomposites with different } \\
\text { concentration of MWCNT on } \\
\text { graphite cathode for the electro- } \\
\text { generation of } \mathrm{H}_{2} \mathrm{O}_{2} \text { by reducing } \\
\text { dissolved oxygen }\end{array}$ & $\begin{array}{l}0.1 \mathrm{~mol} \mathrm{~L}^{-1} \mathrm{Na}_{2} \mathrm{SO}_{4} / \text { graphite } \\
\text { cathode modified with } \\
\text { electrochemically } \\
\text { synthesized polypyrrole } \\
\text { /MWCNT } \\
\text { nanocomposite/ } \\
\text { Optimum operation conditions } \\
\text { are } 0.55 \mathrm{~V} \text { (vs. SCE) and pH= } \\
3 \text { after } 10 \text { min electrolysis. }\end{array}$ & $\begin{array}{l}\text { The cathode modified with } \\
\text { nanocomposite with } 2.5 \% \\
\text { w/w MWCNT (GPM-2.5) } \\
\text { showed highest } \\
\text { electrocatalytic activity. }\end{array}$ & [44] \\
\hline $\begin{array}{l}\text { A simple chemical method using } \\
\text { hydrazine hydrate as the main } \\
\text { reagent was firstly used to } \\
\text { modify graphite felt as cathode } \\
\text { for production of hydrogen } \\
\text { peroxide }\end{array}$ & $\begin{array}{l}\text { Different concentration of } \\
\text { hydrazine hydrate ranging } \\
\text { from } 5 \text { to } 20 \% \text { were studied/ } \\
\text { Chemically modified graphite } \\
\text { felt cathode / } \\
\text { Electrofenton tests were } \\
\text { carried out using p-Np (initial } \\
\text { concentration 50mg/L) as } \\
\text { model pollutant, and 0.05 M } \\
\mathrm{Na}_{2} \mathrm{SO}_{4} \text { as supporting } \\
\text { electrolyte / }\end{array}$ & $\begin{array}{l}\text { The optimum concentration } \\
\text { of the hydrazine hydrate was } \\
10 \% \text {, and the yield of } \mathrm{H}_{2} \mathrm{O}_{2} \\
\text { was as } 2.6 \text { times as that } \\
\text { without modification under } \\
\text { the same conditions. }\end{array}$ & [45] \\
\hline
\end{tabular}




\begin{tabular}{|c|c|c|c|}
\hline $\begin{array}{l}\text { Polyacrylonitrile-based carbon } \\
\text { fiber brush (PAN-CFB) cathode } \\
\text { was used to electro-generate } \\
\text { hydrogen peroxide }\left(\mathrm{H}_{2} \mathrm{O}_{2}\right) \text { via } \\
\text { oxygen reduction reaction } \\
\text { (ORR) and to degrade phenol in } \\
\text { electro-Fenton system. }\end{array}$ & $\begin{array}{l}\mathrm{Na}_{2} \mathrm{SO}_{4} \text { solution containing } \\
\text { phenol of } 100 \mathrm{mg} \mathrm{L}^{-1} \text {, } \\
\mathrm{FeSO}_{4} \cdot 7 \mathrm{H}_{2} \mathrm{O} \text { was added to } \\
\text { supply } \mathrm{Fe}^{2+} / \mathrm{Ti} / \mathrm{IrO} \mathrm{x}_{2}- \\
\mathrm{TiO}_{2} / \mathrm{IrO} \mathrm{I}_{2} \text { mesh anode and } \\
\mathrm{PAN}-\mathrm{CFB} \text { cathode/ } \\
\text { Applied current (50 to } \\
300 \mathrm{~mA}) \text {, cathodic potential (- } \\
0.5 \text { to }-1.2 \mathrm{~V}), \text { electrolyte } \\
\text { concentration }\left(0.03-0.5 \text { mol } \mathrm{L}^{-}\right. \\
\left.{ }^{1}\right) \text { and volume }(2 \text { to } 1 \mathrm{~L}) \text { as well } \\
\text { as electrode distance }(1-5 \\
\text { cm). }\end{array}$ & $\begin{array}{l}\text { PAN-CFB cathode } \\
\text { generated } \mathrm{H}_{2} \mathrm{O}_{2} \text { efficiently } \\
\text { (current efficiency at } \\
300 \mathrm{~mA}>90 \% \text { ), showing high } \\
\text { selectivity regardless of the } \\
\text { electrolyte. }\end{array}$ & [46] \\
\hline $\begin{array}{l}\text { A novel acetylene black-PTFE } \\
\text { cathode for electro-generation of } \\
\text { hydrogen peroxide }\left(\mathrm{H}_{2} \mathrm{O}_{2}\right) \text { was } \\
\text { fabricated using acetylene black } \\
\text { powder (ABP) as catalyst, PTFE } \\
\text { as binder. }\end{array}$ & 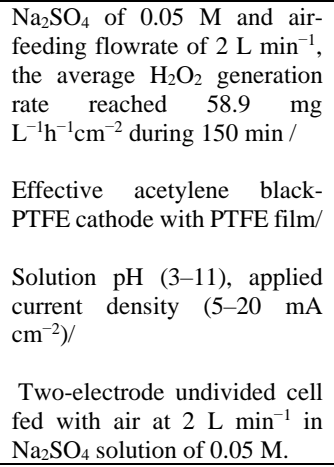 & $\begin{array}{l}\text { High activity of for the } \\
\text { electro-generation of } \mathrm{H}_{2} \mathrm{O}_{2} \\
\text { with air feed, at } \mathrm{pH} 3 \text { and the } \\
\text { current density of } 20 \mathrm{~mA} \\
\mathrm{~cm}^{-2} \text { the average } \mathrm{H}_{2} \mathrm{O}_{2} \\
\text { generation rate reaching } 58.9 \\
\mathrm{mg} \mathrm{L}^{-1} \mathrm{~h}^{-1} \mathrm{~cm}^{-2} \text { during } 150 \\
\text { min of electrolysis and the } \\
\text { current efficiency being } \\
92.7 \% \text {. }\end{array}$ & [47] \\
\hline $\begin{array}{l}\text { A modified Vulcan XC72 } \\
\text { carbon with } \mathrm{WO}_{2.72} \mathrm{NPs} \\
\left(\mathrm{WO}_{2.72} / \text { Vulcan } \mathrm{XC} 72\right) \text { was used } \\
\text { for the preparation of the GDE. }\end{array}$ & $\begin{array}{l}\mathrm{WO}_{2.72} \mathrm{NPs} \text { were supported on } \\
\text { Vulcan XC72 and Printex 6L } \\
\text { carbons at a mass ratio of } 1: 100 \\
\text { (W:C) to evaluate the } \\
\text { electrocatalytic activity for } \\
\text { ORR and } \mathrm{H}_{2} \mathrm{O}_{2} \text { electro- } \\
\text { generation/ } \\
\text { The } \mathrm{WO}_{2.72} / \text { Vulcan XC72 } \\
\mathrm{GDE} \text { cathode was combined } \\
\text { with a Pt or boron-doped } \\
\text { diamond (BDD) anode for the } \\
\text { decolorization of } 0.260 \mathrm{mM} \\
\text { Orange II azo dye solutions by } \\
\text { electrochemical advanced } \\
\text { oxidation processes. }\end{array}$ & $\begin{array}{l}\text { This catalyst is a promising } \\
\text { candidate for application in } \\
\text { EAOPs. }\end{array}$ & [48] \\
\hline $\begin{array}{l}\text { GDEs were constructed using } \\
\text { carbon black either unmodified } \\
\text { or modified with } \mathrm{Ta}_{2} \mathrm{O}_{5} \\
\text { nanoparticles. The properties of } \\
\mathrm{Ta}_{2} \mathrm{O}_{5} / \mathrm{C} \text { for the electrocatalysis } \\
\text { of oxygen reduction by rotating } \\
\text { ring-disk electrode is evaluated. }\end{array}$ & $\begin{array}{l}\text { Nanostructured gas diffusion } \\
\text { electrode. }\end{array}$ & $\begin{array}{l}\text { The current efficiency for } \\
\mathrm{H}_{2} \mathrm{O}_{2} \text { electro-generation on } \\
\mathrm{Ta}_{2} \mathrm{O}_{5} / \mathrm{C} \text { catalyst is } 83.2 \% \\
\text { whereas carbon black } \\
\text { exhibits } 65.3 \% \text {. The } \\
\text { modified GDE produces } \\
27.9 \mathrm{mg} \mathrm{L}^{-1} \text { of } \mathrm{H}_{2} \mathrm{O}_{2} \text {, while } \\
\text { the unmodified } \mathrm{GDE}^{-1} \\
\text { generates } 19.1 \mathrm{mg} \mathrm{L}^{-1} \text { of } \\
\mathrm{H}_{2} \mathrm{O}_{2} \text {. }\end{array}$ & [49] \\
\hline $\begin{array}{l}\text { New air-diffusion cathode } \\
\text { containing } \mathrm{CoS}_{2} \text { nanoparticles to } \\
\text { enhance the } \mathrm{H}_{2} \mathrm{O}_{2} \text { electro- } \\
\text { generation. }\end{array}$ & $\begin{array}{l}\text { Applied current density of } 100 \\
\mathrm{~mA} \mathrm{~cm} \mathrm{~cm}^{-2} \text { for the removal of } \\
\text { tetracaine. }\end{array}$ & $\begin{array}{l}\text { The successful treatment of } \\
\text { tetracaine at } \mathrm{pH} 3.0 \text { and } 100 \\
\mathrm{~mA} \mathrm{~cm} \text { demonstrated the } \\
\text { viability of the manufactured } \\
\mathrm{CoS}_{2} \text {-based cathode. }\end{array}$ & [50] \\
\hline
\end{tabular}




\begin{tabular}{|c|c|c|c|}
\hline $\begin{array}{l}\text { A modified GFs was used as } \\
\text { cathode, a graphite plate as } \\
\text { anode }\end{array}$ & $\begin{array}{l}\mathrm{Na}_{2} \mathrm{SO}_{4} \text { aqueous solution } \\
(5 \mathrm{~g} / \mathrm{L}) \text { was used as the } \\
\text { supporting electrolyte. Prior to } \\
\text { the electrolysis, oxygen }(96 \% \\
\text { purity) was bubbled near the } \\
\text { cathode at a flow rate of } 0.5 \\
\mathrm{~L} / \mathrm{min} \text { for } 10 \mathrm{~min} \text {, and then } \\
\text { oxygen was reduced at a } \\
\text { constant current of } 100 \mathrm{~mA} \text { for } \\
90 \text { min, with a constant stirring } \\
\text { rate of } 300 \mathrm{rpm} \text {. }\end{array}$ & $\begin{array}{l}\text { The } \mathrm{H}_{2} \mathrm{O}_{2} \text { production of } \\
\text { three } \mathrm{GFs} \text { at } 90 \mathrm{~min} \text { were } \\
18.67 \mathrm{mg} / \mathrm{L}, 32.13 \mathrm{mg} / \mathrm{L} \text { and } \\
37.47 \mathrm{mg} / \mathrm{L} \text {, respectively, } \\
\text { compared to only } 3.24 \mathrm{mg} / \mathrm{L} \\
\text { by the original GFs. }\end{array}$ & [51] \\
\hline
\end{tabular}

Thus, opposite to the production of chlorates, fundamental research in the production of hydrogen peroxide is very active and there are many fundamental works related to the optimization of operation conditions (e.g. use of higher pressures or lower temperatures) or to the formulation of new cathodes to make the process more efficient and to try to approach the efficiency of the widely applied chemical process. However, it is important to increase dramatically the TRL of these studies, in particular regarding the cathode stability and catalytic behavior, so there is still gap for further research in this topic over the next years.

\section{Production of chlorine dioxide from chlorate and hydrogen peroxide}

Although typically chlorine dioxide is produced by the chemical combination of chlorite and hypochlorite/chlorine or hydrochloric acid, in this review we are focusing on the production of this reagent from two species that can be easily produced onsite by electrochemical technology. The reaction shown in equation (13) requires strong acidic media and produces oxygen as byproduct

$$
\mathrm{ClO}_{3}^{-}+1 / 2 \mathrm{H}_{2} \mathrm{O}_{2}+\mathrm{H}^{+} \rightarrow \mathrm{ClO}_{2}(\mathrm{aq})+\frac{1}{2} \mathrm{O}_{2}+\mathrm{H}_{2} \mathrm{O}
$$

Regarding this reaction, and its alternatives in which methanol of sulfur dioxide are used as reductants of chlorate to produce the chlorine dioxide, there are many works published recently. The most relevant data of various of the most interesting are summarized in Table 3, where it can be seen, that formation of chloride dioxide is very efficient, but a good adjustment of operation conditions should be done. Also, that hydrogen peroxide exhibit advantages over the use of methanol in terms of a more sustainable solution, which avoid the formation of hazardous species such as formaldehyde. Not least important the possibility of preparing portable solutions which can help to expand the use of chloride dioxide for the disinfection of buildings. 
Table 3. Scientific works related to chemical chlorine dioxide production

\begin{tabular}{|c|c|c|c|c|}
\hline $\begin{array}{l}\text { Objective / Technology } \\
\text { evaluated }\end{array}$ & $\begin{array}{l}\text { Reagents } \\
\text { (concentration)/ } \\
\text { electrode type }\end{array}$ & operation conditions & Main conclusions & Ref. \\
\hline $\begin{array}{l}\text { Cleaner production } \\
\text { process for producing } \\
\text { sodium chlorite by } \\
\text { reducing sodium } \\
\text { chlorate with hydrogen } \\
\text { peroxide in the } \\
\text { presence of sulfuric } \\
\text { acid. }\end{array}$ & $\begin{array}{l}\text { Temperature: } 50-70{ }^{\circ} \mathrm{C} \text {; } \\
\text { Concentration of sulfuric } \\
\text { acid: } 4-5.5 \text { mol L } \mathrm{L}^{-1} \text {; } \\
\text { concentration of sodium } \\
\text { chlorate: } 400-650 \mathrm{~g} \mathrm{~L}^{-1} \\
\text { and molar ratio of } \\
\text { hydrogen peroxide to } \\
\text { sodium chlorate } 0.5- \\
0.7 \text {. }\end{array}$ & $\begin{array}{l}\text { Ambient air is used to mix the } \\
\text { reaction liquid and to dilute the } \\
\text { generated chlorine dioxide. The } \\
\text { generated chlorine dioxide is } \\
\text { introduced to and absorbed } \\
\text { through a series of three } \\
\text { absorbers. }\end{array}$ & $\begin{array}{l}\text { Sodium chlorate conversion to } \\
\text { sodium chlorite of } 95-100 \% \text {. } \\
\text { Waste acid in the chlorine } \\
\text { dioxide generator is } \\
\text { dramatically reduced with } \\
\text { recycling in the new process. } \\
\text { The by-produced sodium } \\
\text { sulfate in sulfuric acid is } \\
\text { minimized and reclaimed. }\end{array}$ & {$[52]$} \\
\hline $\begin{array}{l}\text { Determine } \\
\text { formaldehyde and } \\
\text { carbon dioxide are } \\
\text { formed in the methanol- } \\
\text { chlorate process. }\end{array}$ & $\begin{array}{l}0.05 \mathrm{M} \text { by diluting neat } \\
\text { methanol, } 0.25 \mathrm{M} \\
\text { sodium carbonate } \\
\text { solution, solution of } \mathrm{CO}_{2} \\
\text { in sulfuric acid was } \\
\text { generated by injecting } \\
0.5 \mathrm{~mL} \text { of the labeled } \\
\text { sodium carbonate } \\
\text { solution into a } 4.5-\mathrm{mL} \\
\text { solution of } 2.8 \mathrm{M} \text { sulfuric } \\
\text { acid. }\end{array}$ & $\begin{array}{l}\text { Formaldehyde is detectable at } \\
\text { mild oxidative conditions, } \\
\text { including ambient temperature } \\
\text { and low chlorate to methanol } \\
\text { ratio/ } \\
\text { Carbon dioxide was detected at } \\
\text { conditions in the range of } \\
\text { commercial operation but not } \\
\text { under the mild conditions used to } \\
\text { detect formaldehyde. }\end{array}$ & $\begin{array}{l}\text { Adding a low concentration of } \\
\text { chlorine to the reaction } \\
\text { solution increased the } \\
\text { production of carbon dioxide } \\
\text { at ambient temperature. }\end{array}$ & {$[53]$} \\
\hline $\begin{array}{lc}\text { Description } & \text { of } a \\
\text { portable } & \text { chlorine } \\
\text { dioxide } & \left(\mathrm{ClO}_{2}\right) \\
\text { generation system to } \\
\text { decontaminate } \\
\text { buildings contaminated } \\
\text { with B. anthracis } \\
\text { spores. }\end{array}$ & $\begin{array}{l}\text { Development and field } \\
\text { testing of a mobile } \\
\text { chlorine dioxide } \\
\text { generation system for the } \\
\text { decontamination of } \\
\text { buildings contaminated } \\
\text { with Bacillus anthracis }\end{array}$ & $\begin{array}{l}\text { The system } \\
\text { satisfactorily }\end{array}$ & $\begin{array}{l}\text { Measurement of } \mathrm{ClO}_{2} \text { levels at } \\
\text { the generator outlet showed } \\
\text { that the desired production rate } \\
\text { was not achieved. }\end{array}$ & {$[54]$} \\
\hline $\begin{array}{l}\text { Evaluation of the } \\
\text { production and stability } \\
\text { of chlorine dioxide } \\
\left(\mathrm{ClO}_{2}\right) \text { in organic acid } \\
\text { solutions and its } \\
\text { effectiveness in killing } \\
\text { Bacillus cereus spores }\end{array}$ & $\begin{array}{l}100 \text { or } 50 \mu \mathrm{g} / \mathrm{ml} \text { in } \\
\text { organic acid solutions }\end{array}$ & $\begin{array}{l}\text { Sodium chlorite }(5000,10,000 \text {, or } \\
50,000 \mu \mathrm{g} / \mathrm{ml}) \text { was added to } 5 \% \\
\text { acetic, citric, or lactic acid } \\
\text { solution, adjusted to } \mathrm{pH} 3.0,4.0 \text {, } \\
5.0 \text {, or } 6.0 \text {, and held at } 21{ }^{\circ} \mathrm{C} \text { for } \\
\text { up to } 14 \text { days. }\end{array}$ & $\begin{array}{l}\text { The amount of } \mathrm{ClO}_{2} \text { produced } \\
\text { was higher as the } \\
\text { concentration of sodium } \\
\text { chlorite was increased and as } \\
\text { the pH of the acid solutions } \\
\text { was decreased. } \\
\text { The stability in production of } \\
\mathrm{ClO}_{2} \text { was enhanced by } \\
\text { increasing the pH of the } \\
\text { organic acid solutions. }\end{array}$ & {$[55]$} \\
\hline $\begin{array}{l}\text { Determination of the } \\
\text { optimum conditions for } \\
\text { the production of } \\
\text { gaseous chlorine } \\
\text { dioxide }\left(\mathrm{ClO}_{2}\right) \text { from } \\
\text { aqueous } \mathrm{ClO}_{2} \\
\left(\mathrm{HCl}+\mathrm{NaClO}_{2}\right) \text { (useful } \\
\text { information for } \\
\text { designing a sanitization } \\
\text { program using gaseous } \\
\mathrm{ClO}_{2} \text { under various } \\
\text { environmental } \\
\text { conditions). }\end{array}$ & $\begin{array}{l}\mathrm{NaClO}_{2} \quad(50,000- \\
500,000 \mathrm{mg} / \mathrm{mL})\end{array}$ & $\begin{array}{l}\text { Reaction of } 1 \mathrm{~N} \mathrm{HCl} \text { with various } \\
\text { concentrations of } \mathrm{NaClO}_{2} \\
(50,000-500,000 \mathrm{mg} / \mathrm{mL}) / \\
\text { Effects of relative humidity (RH; } \\
43,85 \text {, and } 100 \%) \text { and } \\
\text { temperature }\left(4,12 \text {, and } 25^{\circ} \mathrm{C}\right) \text {. }\end{array}$ & $\begin{array}{l}\text { It was observed that the } \\
\text { concentration of gaseous } \mathrm{ClO}_{2} \\
\text { was increased as } \mathrm{RH} \text { was } \\
\text { decreased, or the temperature } \\
\text { was increased. Finally, it was } \\
\text { confirmed that the amount of } \\
\text { gaseous } \mathrm{ClO}_{2} \text { was highly } \\
\text { correlated }\left(\mathrm{R}^{2}=0.9546-\right. \\
0.9992) \text { with the volume of } \\
\text { aqueous } \mathrm{ClO}_{2} \text {. }\end{array}$ & {$[56]$} \\
\hline $\begin{array}{l}\text { The effect of adding } \\
\text { hydrogen peroxide on a } \\
\text { methanol-based } \\
\text { chlorine dioxide } \\
\text { generation process was } \\
\text { studied. }\end{array}$ & $\begin{array}{l}3 \mathrm{~mol} / \mathrm{L} \mathrm{H}_{2} \mathrm{SO}_{4}, 70{ }^{\circ} \mathrm{C} \text {, } \\
0.97 \mathrm{~mol} / \mathrm{L} \mathrm{NaClO} \text {, total } \\
\text { reducing agent } 0.01 \\
\text { mol/L }\end{array}$ & $\begin{array}{l}\text { In a continuous generator at } 6 \\
\text { mol/L } \mathrm{H}_{2} \mathrm{SO}_{4} \text { acidity under } \\
\text { atmospheric pressure, by } \\
\text { substituting } 10 \% \text { of the methanol } \\
\text { with hydrogen peroxide of an } \\
\text { equivalent reducing strength, the }\end{array}$ & $\begin{array}{l}\text { Chlorine dioxide generation is } \\
\text { increased and that chlorine, } \\
\text { usually present as a byproduct } \\
\text { in the chlorine dioxide } \\
\text { solution, can be largely } \\
\text { eliminated when hydrogen }\end{array}$ & {$[57]$} \\
\hline
\end{tabular}




\begin{tabular}{|c|c|c|c|c|}
\hline & & $\begin{array}{l}\text { generation rate of chlorine } \\
\text { dioxide is doubled. }\end{array}$ & $\begin{array}{l}\text { peroxide is present as a co- } \\
\text { reducing agent. }\end{array}$ & \\
\hline $\begin{array}{l}\text { Evaluation of reaction } \\
\text { mechanisms during the } \\
\text { manufacturing of } \\
\text { chlorine dioxide from } \\
\text { the reduction of sodium } \\
\text { chlorate with hydrogen } \\
\text { peroxide. }\end{array}$ & $\begin{array}{l}\text { In each experiment, } \\
\text { measured amounts of } \\
\text { hydrogen peroxide, } \\
\text { sulfuric acid and water } \\
\text { were first added to the } \\
\text { reaction flask and } \\
\text { equilibrated to the bath } \\
\text { temperature. }\end{array}$ & $\begin{array}{l}\text { The side-reaction rate was } \\
\text { compared with the rate that } \\
\text { chlorine dioxide is produced } \\
\text { under a typical set of industrial } \\
\text { conditions: } 80{ }^{\circ} \mathrm{C}, 2 \mathrm{M} \text { sulfuric } \\
\text { acid, } 3.4 \mathrm{M} \text { sodium chlorate and } \\
3.2 \mathrm{M} \text { sodium sulfate. }\end{array}$ & $\begin{array}{l}\text { At the cited industrial } \\
\text { conditions, the reaction model } \\
\text { predicts that chlorine dioxide } \\
\text { is consumed by the side- } \\
\text { reaction at about } 0.8 \%-1.5 \% \text { of } \\
\text { the rate at which it is produced. }\end{array}$ & {$[57]$} \\
\hline $\begin{array}{l}\text { The development of } \\
\text { chlorine containing } \\
\text { species during the } \\
\text { hydrogen peroxide- } \\
\text { based chlorine dioxide } \\
\text { generation process has } \\
\text { been determined. }\end{array}$ & 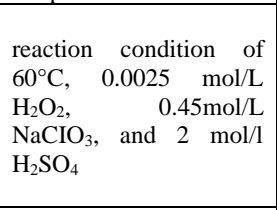 & $\begin{array}{l}\text { Accordingly, two distinct phases, } \\
\text { namely the induction period and } \\
\text { the steady-state phase, were } \\
\text { identified. }\end{array}$ & $\begin{array}{l}\text { It is demonstrated the viability } \\
\text { of the reaction between chloric } \\
\text { acid and chlorous acid, which } \\
\text { is responsible for the } \\
\text { generation of chlorine dioxide } \\
\text { in the hydrogen peroxide- } \\
\text { based } \mathrm{CIO}_{2} \text {, process }\end{array}$ & [58] \\
\hline $\begin{array}{l}\text { Chlorine dioxide } \\
\text { formation by reduction } \\
\text { of sodium chlorate with } \\
\text { hydrogen peroxide in } \\
\text { aqueous sulfuric acid/ } \\
\text { The rate of reaction } \\
\text { was studied in both } \\
\text { batch and well-mixed } \\
\text { reactors over ranges of } \\
\text { temperature and } \\
\text { reactant concentrations } \\
\text { which bracket } \\
\text { conditions of } \\
\text { commercial interest. }\end{array}$ & $\begin{array}{l}2 \mathrm{M} \text { sodium chlorate and } \\
2.6 \mathrm{M} \text { sulfuric acid }\end{array}$ & $\begin{array}{l}\text { The rate data were correlated by a } \\
\text { power law model in which an } \\
\text { acidity function H- was used to } \\
\text { characterize the acidity of } \\
\text { sulfuric acid. }\end{array}$ & $\begin{array}{l}\text { The rate model reasonably } \\
\text { predicted transient chlorine } \\
\text { dioxide production rate data } \\
\text { gathered in a commercial plant } \\
\text { trial. The rate model should } \\
\text { provide a useful tool for } \\
\text { design. }\end{array}$ & [59] \\
\hline $\begin{array}{l}\text { The reaction between } \\
\text { sodium chlorate and } \\
\text { sodium chloride in } \\
\text { presence of aqueous } \\
\text { sulfuric acid is studied }\end{array}$ & $\begin{array}{l}\text { Well stirred reactor at } \\
\text { various temperatures and } \\
\text { molar concentrations of } \\
\text { chlorate, chloride }\end{array}$ & $\begin{array}{l}\text { Reaction has been found first and } \\
\text { second order with respect to } \\
\text { chlorate and chloride } \\
\text { concentration, respectively. }\end{array}$ & $\begin{array}{l}\text { The temperature dependence } \\
\text { of the reaction is also } \\
\text { investigated and pre- } \\
\text { exponential Arrhenius } \\
\text { parameter as well as activation } \\
\text { energy are determined. } \\
\mathrm{ClO}_{2} / \mathrm{Cl}_{2} \text { ratio is markedly } \\
\text { affected by chlorate to chloride } \\
\text { ratio. }\end{array}$ & [16] \\
\hline $\begin{array}{l}\text { Reaction paths } \\
\text { governing chlorine } \\
\text { dioxide formation from } \\
\text { solutions of sodium } \\
\text { chlorate, sulfuric acid, } \\
\text { hydrogen peroxide and } \\
\text { sodium chloride were } \\
\text { examined. }\end{array}$ & $\begin{array}{l}2 \mathrm{M} \mathrm{H}_{2} \mathrm{SO}_{4}, 2 \mathrm{M} \mathrm{NaClO} \\
0.1 \mathrm{M} \mathrm{H}_{2} \mathrm{O}_{2} \text { and } 0.01 \mathrm{M} \\
\mathrm{NaCl} \\
\text { Temperature } 25^{\circ} \mathrm{C}\end{array}$ & $\begin{array}{l}\text { At conditions of this study, the } \\
\text { rate of the chloride-chlorate path } \\
\text { predominated and was enhanced } \\
\text { by hydrogen peroxide, reaching } \\
\text { an upper limit as hydrogen } \\
\text { peroxide concentration was } \\
\text { increased. }\end{array}$ & $\begin{array}{l}\text { Chlorine dioxide was formed } \\
\text { by two paths: the reduction of } \\
\text { chlorate by hydrogen peroxide } \\
\text { and the reduction of chlorate } \\
\text { by chloride. }\end{array}$ & [60] \\
\hline $\begin{array}{l}\text { Reaction between } \\
\text { chlorous acid and } \\
\text { hypochlorous acid in } \\
\text { sulfuric acid solution } \\
\text { was studied. }\end{array}$ & $\begin{array}{l}\text { The concentrations of } \\
\text { sulfuric acid, } \\
\text { hypochlorous acid and } \\
\text { chlorous acid were, } 4.5 \\
\mathrm{~mol} / \mathrm{L}, 0.5 \mathrm{mmol} / \mathrm{L} \text { and } \\
1.0 \quad \mathrm{mmol} / \mathrm{L}, \\
\text { respectively. }\end{array}$ & $\begin{array}{l}\text { Under the conditions of } 0.5 \\
\mathrm{mmol} / \mathrm{L} \text { hypochlorous acid, } 1 \\
\mathrm{mmol} / \mathrm{L} \text { chlorous acid, } 4.5 \mathrm{~mol} / \mathrm{L} \\
\text { sulfuric acid, and } 25^{\circ} \mathrm{C} \text {, within } 30 \\
\text { seconds of reaction time, it was } \\
\text { found that in the reaction solution } \\
\text { there were } 0.64 \mathrm{mmol} / \mathrm{L} \text { chloric } \\
\text { acid and } 0.58 \mathrm{mmol} \mathrm{Cl} \text {, and } \mathrm{HOCl}\end{array}$ & $\begin{array}{l}\text { It was found that chlorine } \\
\text { dioxide is generated only if } \\
\text { chloride is present. }\end{array}$ & {$[61]$} \\
\hline
\end{tabular}

However, the production of chlorine dioxide using electrochemical technology has also been the target of many other studies, such as those shown in Table 4, where it can be seen that MMO electrodes remains as the most important choice of anode and that production of chlorine dioxide using chlorite is the most widely 
electrochemical systems studied. It is important to highlight that 1) despite of the industrial production of chlorate by electrochemical technology and the promising results obtained by the electrogeneration of hydrogen peroxide and 2) the most sustainable pathway to produce chlorine dioxide as compared with other routes, there are no works trying to integrated both processes. This means that there is still a very important gap in the scientific knowledge to be fulfilled with the integration of the anodic production of chlorate and the cathodic production of hydrogen peroxide.

Table 4. Scientific works related to electrochemical chlorine dioxide production

\begin{tabular}{|c|c|c|c|c|}
\hline $\begin{array}{l}\text { Objective / Technology } \\
\text { evaluated }\end{array}$ & $\begin{array}{l}\text { Reagents } \\
\text { (concentration)/ } \\
\text { electrode type }\end{array}$ & operation conditions & Main conclusions & Ref. \\
\hline $\begin{array}{l}\text { The effect of the feed } \\
\text { flow rate, initial feed } \\
\mathrm{pH} \text {, the concentration } \\
\text { of } \mathrm{NaCl} \text { salt, the } \\
\text { concentration of } \\
\mathrm{NaClO}_{2} \text { precursor, and } \\
\text { the applied current on } \\
\text { the generation of } \mathrm{ClO}_{2} \\
\text { was studied using } \mathrm{IrO}_{2-} \\
\text { coated-Ti as the anode. }\end{array}$ & $\begin{array}{l}\text { Feed solution containing } \\
\text { a mixture of } \mathrm{NaClO}_{2} \text { and } \\
\mathrm{NaCl} \text { was directly } \\
\text { introduced into the } \\
\text { electrolytic and cell } \\
\text { assembly, and } \mathrm{ClO}_{2} \\
\text { generation experiments } \\
\text { were performed by } \\
\text { single-pass system } \\
\text { without recirculation. }\end{array}$ & 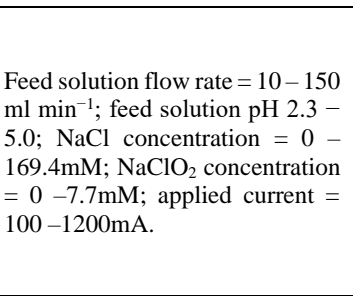 & $\begin{array}{l}\text { The constant current } \\
\text { electrolysis of } \mathrm{NaCl}-\mathrm{NaClO}_{2} \\
\text { mixture solution by single- } \\
\text { pass arrangement offers an } \\
\text { easy way for on-line } \\
\text { generation of } \mathrm{ClO}_{2} \text { gas in } \\
\text { solution. }\end{array}$ & {$[62]$} \\
\hline $\begin{array}{l}\text { Problems of chlorine } \\
\text { dioxide formation and } \\
\text { reactions during and } \\
\text { after electrolysis. First } \\
\text { results are presented, } \\
\text { which were obtained in } \\
\text { synthetic and real } \\
\text { drinking waters using } \\
\text { titanium anodes with } \\
\mathrm{IrO}_{2} / \mathrm{RuO}_{2} \text { coatings }\end{array}$ & $\begin{array}{l}\text { Discontinuous } \\
\text { electrolysis experiments } \\
\text { were performed using } \\
\text { activated titanium } \\
\text { anodes containing } \mathrm{IrO}_{2} \\
\text { and } \mathrm{RuO}_{2}\end{array}$ & $\begin{array}{l}\text { The influence of chloride } \\
\text { concentration up to } 250 \mathrm{mg} \mathrm{L}^{-1} \text {, } \\
\text { current density (up to } 500 \mathrm{Am}^{-2} \text { ) } \\
\text { and other parameters on } \mathrm{ClO}_{2} \\
\text { formation is shown. }\end{array}$ & $\begin{array}{l}\text { Chlorine dioxide is efficiently } \\
\text { produced }\end{array}$ & [14] \\
\hline $\begin{array}{l}\text { Evaluation of the effect } \\
\text { of voltage, anolyte, } \\
\text { catholyte, and } \mathrm{pH} \text { on } \\
\text { the production of } \mathrm{ClO}_{2} \\
\text { by an electrolytic } \\
\text { method }\end{array}$ & $\begin{array}{l}\text { The } \mathrm{NaClO}_{2} \text { was } \\
\text { selected as the } \\
\text { compositions of anolyte/ } \\
\text { Titanium anode } \\
\text { containing noble metals } \\
\text { and geometry grid to } \\
\text { increase its activation }\end{array}$ & $\begin{array}{l}\text { Working voltage: } 6 \mathrm{~V}, 8 \mathrm{~V}, 10 \mathrm{~V}, \\
\text { and } 12 \mathrm{~V} ; \text { Catholyte }(\mathrm{NaOH}): 0 \\
\%, 0.1 \%, 0.3 \%, 0.5 \%, \text { and } 0.7 \\
\% ; \text { Anolyte }(\mathrm{NaCl}): 2 \%, 4 \%, 6 \\
\%, 8 \%, \text { and } 10 \% ; \text { Anolyte } \\
\left(\mathrm{NaClO}_{2}\right): 0.5 \%, 1 \%, 2 \%, 4 \%, \\
\text { and } 6 \% ; \mathrm{pH} \text { value (anolyte): } 2,7, \\
\text { and } 12 .\end{array}$ & $\begin{array}{l}\text { The maximum concentration } \\
\text { and purity of the } \mathrm{ClO}_{2} \text { were } \\
302.01 \mathrm{mg} / \mathrm{L} \text { and } 91 \% \text {, } \\
\text { respectively, with a mixture of } \\
2 \% \text { sodium chloride }(\mathrm{NaCl}) \\
\text { and } 6 \% \text { sodium chlorite } \\
\left(\mathrm{NaClO}_{2}\right) \text {. }\end{array}$ & {$[63]$} \\
\hline $\begin{array}{l}\text { Evaluation of the } \\
\text { electrolytic generation } \\
\text { of dissolved chlorine } \\
\text { dioxide from an un- } \\
\text { buffered solution of } \\
\text { sodium chlorite and } \\
\text { sodium chloride } \\
\text { mixture in an un- } \\
\text { divided } \\
\text { electrochemical cell } \\
\text { set-up with } \mathrm{RuO}_{2^{-}} \\
\text {coated-Ti anode and Pt- } \\
\text { coated-Ti cathode } \\
\text { under constant current } \\
\text { mode. }\end{array}$ & $\begin{array}{l}\text { Mixture of } \mathrm{NaClO}_{2} \text { and } \\
\mathrm{NaCl} / \mathrm{The} \text { anode and } \\
\text { cathode were } 2 \mathrm{~mm} \text { thick } \\
\text { mesh type } \mathrm{RuO}_{2} / \mathrm{Ti} \text { and } \\
\mathrm{Pt} / \mathrm{Ti} \text { plates, } \\
\text { respectively. }\end{array}$ & $\begin{array}{l}\text { Feed solution flow rate }=10 \text { to } \\
150 \mathrm{~mL} / \mathrm{min} \text {; feed solution } \mathrm{pH}= \\
2.3 \text { to } 9.4 ; \mathrm{NaCl} \text { concentration }= \\
0 \quad \text { to } 170 \mathrm{mM} ; \quad \mathrm{NaClO}_{2} \\
\text { concentration }=0 \text { to } 7.7 \mathrm{mM} \text {; } \\
\text { current }=100 \text { to } 1200 \mathrm{~mA}(8.4 \text { to } \\
101.4 \mathrm{~mA} / \mathrm{cm}^{2} \text { of effective } \\
\text { surface area). }\end{array}$ & $\begin{array}{l}\text { Experiments were conducted } \\
\text { by performing single pass } \\
\text { experiments, with no } \\
\text { circulation. The current } \\
\text { efficiency and the power } \\
\text { Consumption were calculated } \\
\text { for the optimized conditions } \\
\text { and compared with IrO }{ }_{2} \\
\text { electrode of our previous } \\
\text { investigation. }\end{array}$ & [64] \\
\hline $\begin{array}{l}\text { A titanium anode } \\
\text { coated in ruthenium } \\
\text { generates the largest } \\
\text { amount of active }\end{array}$ & $\begin{array}{l}\text { The electrode plate uses } \\
\text { a titanium plate as the } \\
\text { cathode, and the anode } \\
\text { plate uses a grid-formed }\end{array}$ & $\begin{array}{l}\text { Sodium chlorite is added into the } \\
\text { brine and an electrolysis reaction } \\
\text { is performed at } 40^{\circ} \mathrm{C} \text { and } 12 \mathrm{~V} \text { for } \\
\text { batch operation. }\end{array}$ & $\begin{array}{l}\text { During continuous } \\
\text { electrolysis, when the inflow } \\
\text { rate for the anode electrolyte is } \\
\text { increased to } 120 \mathrm{~mL} \mathrm{m^{-1 }} \text {, }\end{array}$ & {$[65]$} \\
\hline
\end{tabular}




\begin{tabular}{|l|l|l|l|l|}
\hline $\begin{array}{l}\text { chlorine (chlorine } \\
\text { dioxide) during the } \\
\text { electrolysis of brine in } \\
\text { seawater desalination } \\
\text { plants }\end{array}$ & $\begin{array}{l}\text { titanium plate as the } \\
\text { substrate. }\end{array}$ & & $\begin{array}{l}\mathrm{ClO}_{2} \text { is produced at a constant } \\
\text { concentration of } 60 \mathrm{mg} \mathrm{L}^{-1} \\
\text { after 30 minutes. }\end{array}$ \\
\hline
\end{tabular}

Anyhow, if the results published in scientific journals are interesting, it is worth to point out that the information available from patents is even more exciting, because it reflects the real interest in the spreading of the technology to allow its commercialization. Some of the recent patents are shown in Table 5, where it can be seen (two first rows) that chemical production of chlorine dioxide still remains to be a topic of interest for companies and that there is also interest from companies to produce electrolytically chloride dioxide, although the chlorite method, as it happens with the scientific literature, focusses still the main interest, perhaps because of the ease of the technology.

Table 5. Several recent patents related with the chemical and electrochemical production of chlorine dioxide

\begin{tabular}{|c|c|c|c|}
\hline Year / Title & $\begin{array}{l}\text { Field of the invention } \\
\text { /justification }\end{array}$ & Summary of the invention (as in the patent document) & Ref. \\
\hline $\begin{array}{l}2013 \text { / Production of } \\
\text { chlorine dioxide } \\
\text { release material }\end{array}$ & $\begin{array}{l}\text { Process to produce chlorine } \\
\text { dioxide release materials } \\
\text { Chlorine dioxide generating } \\
\text { system that is suitable for } \\
\text { industrial applications }\end{array}$ & $\begin{array}{l}\text { "Process for the production of a chlorine dioxide release } \\
\text { material comprising the steps of: a) admixing a metal } \\
\text { chlorite salt solution or suspension and a dehydrating } \\
\text { agent; b) admixing a dry and/or anhydrous acid source } \\
\text { capable of donating protons to chlorine dioxide generation } \\
\text { reactions, with said metal chlorite salt and dehydrating } \\
\text { agent to a mixture." }\end{array}$ & [66] \\
\hline $\begin{array}{lr}2015 \text { / } & \text { Process to } \\
\text { produce } & \text { chlorine } \\
\text { dioxide } & \end{array}$ & $\begin{array}{l}\text { Process to produce chlorine } \\
\text { dioxide, which allows the } \\
\text { generation of chlorine dioxide gas } \\
\text { at a selected pressure. } \\
\text { The present invention is to provide } \\
\text { an efficient process for producing } \\
\text { chlorine dioxide at sub- } \\
\text { atmospheric pressure that is } \\
\text { suitable for applications in which } \\
\text { chlorine dioxide gas is used. }\end{array}$ & $\begin{array}{l}\text { "Process for the continuous production of chlorine dioxide } \\
\text { comprising generating chlorine dioxide in an aqueous } \\
\text { reaction medium in a reaction vessel (1) maintained at sub- } \\
\text { atmospheric pressure, bringing gaseous chlorine dioxide } \\
\text { from said reaction vessel to an absorption tower (7) and } \\
\text { contacting it therein with a flow of water to form an } \\
\text { aqueous solution containing chlorine dioxide, bringing said } \\
\text { aqueous solution containing chlorine dioxide to a stripper } \\
\text { (12), blowing a gas through said aqueous solution of } \\
\text { chlorine dioxide in the stripper to strip off from } 10 \text { to } 100 \% \\
\text { of the chlorine dioxide entering the stripper and form a } \\
\text { gaseous chlorine dioxide product." }\end{array}$ & [67] \\
\hline $\begin{array}{l}2014 \text { / Process and } \\
\text { combined plant of } \\
\text { production of chlorine } \\
\text { dioxide for water } \\
\text { treatment through } \\
\text { desinfection }\end{array}$ & $\begin{array}{l}\text { Process and a combined plant of } \\
\text { production of chlorine dioxide for } \\
\text { water treatment through } \\
\text { disinfection. } \\
\text { The process and the plant allow to } \\
\text { overcome the limits of the } \\
\text { solutions according to the prior art } \\
\text { and to obtain the technical results } \\
\text { previously described. }\end{array}$ & $\begin{array}{l}\text { "Water treatment combined plant, comprising at least one } \\
\text { electro-chlorinator (1) for producing sodium hypochlorite } \\
\text { in solution, a first reaction chamber ( } 4 \text { ) to which sodium } \\
\text { hypochlorite coming from said electro-chlorinator (1) and } \\
\text { an acid solution coming from a first storage tank (13) and } \\
\text { dosed by means of a first dosing section (2) arrive and from } \\
\text { which a chlorine solution comes out, a second reaction } \\
\text { chamber (5) to which said chlorine solution coming from } \\
\text { said first reaction chamber (4) and a sodium chlorite } \\
\text { solution arrive, coming from a second storage tank (14) and } \\
\text { dosed by means of a second dosing section (3) and from } \\
\text { which a chlorine solution dioxide comes out and an } \\
\text { injection point (9) of said chlorine solution dioxide in a } \\
\text { water treatment section." }\end{array}$ & [68] \\
\hline $\begin{array}{l}2010 / \text { Method for } \\
\text { producing chlorine } \\
\text { dioxide }\end{array}$ & $\begin{array}{l}\text { Process for the production of } \\
\text { chlorine dioxide by the reaction of } \\
\text { chlorine and chlorite. Chlorine } \\
\text { dioxide can be produced }\end{array}$ & $\begin{array}{l}\text { "Chlorine is generated electrochemically in a first process } \\
\text { step from a saturated sodium chloride solution, wherein } \\
\text { sodium hydroxide solution and hydrogen gas are generated } \\
\text { in a cathode chamber, and chlorine is generated in an anode } \\
\text { chamber, and, in a second process step, the generated }\end{array}$ & [69] \\
\hline
\end{tabular}




\begin{tabular}{|c|c|c|c|}
\hline & $\begin{array}{lll}\text { economically and } & \text { with } \\
\text { comparatively little effort. } & \\
\end{array}$ & $\begin{array}{l}\text { chlorine is reacted in a reactor with sodium chlorite with } \\
\text { the addition of an acid to form chlorine dioxide." }\end{array}$ & \\
\hline 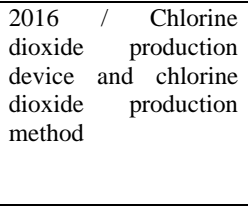 & $\begin{array}{l}\text { A device and a method for } \\
\text { producing chlorine dioxide by } \\
\text { electrolyzing anolyte solution } \\
\text { containing chlorite with using a } \\
\text { diaphragm electrolytic cell having } \\
\text { an anode chamber and a cathode } \\
\text { chamber. }\end{array}$ & $\begin{array}{l}\text { "A device and a method for generating chlorine dioxide by } \\
\text { implementing an electrolytic treatment while supplying an } \\
\text { amount of anolyte solution containing chlorite and an } \\
\text { amount of catholyte solution containing e.g. sodium } \\
\text { hydroxide, sodium chloride etc. to an anode chamber and a } \\
\text { cathode chamber respectively of a diaphragm electrolytic } \\
\text { cell." }\end{array}$ & [70] \\
\hline
\end{tabular}

In this context, the development of more robust methods for the production of hydrogen peroxide and the finding of the conditions in which both electrochemical processes can be integrated may become a turning point for the development of the technology.

\section{Conclusions}

From this work, the following conclusions can be drawn:

- Chlorate production is at a very high TRL but there is still scientific interest in testing novel electrodes such as the diamond coatings to improve performance. Also, it is of interest the complete understanding of the role of chromium in the efficient production of chlorates and the ways to promote or prevent chlorate formation during the electrolysis of aqueous solutions containing chloride.

- Hydrogen peroxide production by electrochemical methods is at a lower TRL and many studies are being conducted trying to find optimum operation conditions, suitable cell designs and specially good formulations of the cathode material, trying to attain suitable electrocatalytic properties and high robustness. Large efforts should be made in the recent years to make this process competitive.

- Chloride dioxide can be produced chemically from the reduction at strongly acidic media of chlorates.

However, according to most of the scientific literature and patents the production from chlorite is preferred and there should be made a great scientific effort to cover the gap with the integration of electrochemical production of chlorates and hydrogen peroxide.

\section{Acknowledgements}

Financial support from the Spanish Agencia Estatal de Investigación throughout project PID2019-107271RBI00 is gratefully acknowledged. Mayra Monteiro also acknowledges CNPq- Conselho Nacional de Desenvolvimiento Científico e Tecnológico for process number 202069/2019-2 (modalidade:doutorado sanuíche no Exterior-SWE). 


\section{Literature cited}

[1] S. Bebelis, K. Bouzek, A. Cornell, M.G.S. Ferreira, G.H. Kelsall, F. Lapicque, C. Ponce de León, M.A. Rodrigo, F.C. Walsh, Highlights during the development of electrochemical engineering, Chemical Engineering Research and Design, 91 (2013) 19982020.

[2] C.A. Martínez-Huitle, M.A. Rodrigo, I. Sirés, O. Scialdone, Single and Coupled Electrochemical Processes and Reactors for the Abatement of Organic Water Pollutants: A Critical Review, Chemical Reviews, 115 (2015) 13362-13407.

[3] P. Canizares, C. Saez, A. Sanchez-Carretero, M.A. Rodrigo, Synthesis of novel oxidants by electrochemical technology, Journal of Applied Electrochemistry, 39 (2009) 2143-2149.

[4] K. Serrano, P.A. Michaud, C. Comninellis, A. Savall, Electrochemical preparation of peroxodisulfuric acid using boron doped diamond thin film electrodes, Electrochimica Acta, 48 (2002) 431-436.

[5] P. Canizares, F. Larrondo, J. Lobato, M.A. Rodrigo, C. Saez, Electrochemical synthesis of peroxodiphosphate using borondoped diamond anodes, Journal of the Electrochemical Society, 152 (2005) D191-D196.

[6] S. Velazquez-Pena, C. Saez, P. Canizares, I. Linares-Hernandez, V. Martinez-Miranda, C. Barrera-Diaz, M.A. Rodrigo,

Production of oxidants via electrolysis of carbonate solutions with conductive-diamond anodes, Chemical Engineering Journal, 230 (2013) 272-278

[7] J. Llanos, I. Moraleda, C. Saez, M.A. Rodrigo, P. Canizares, Optimization of a cell for the electrochemical synergistic production of peroxoacetic acid, Electrochimica Acta, 260 (2018) 177-183.

[8] J. Llanos, I. Moraleda, C. Saez, M.A. Rodrigo, P. Canizares, Electrochemical production of perchlorate as an alternative for the valorization of brines, Chemosphere, 220 (2019) 637-643

[9] C. Saez, P. Canizares, A. Sanchez-Carretero, M.A. Rodrigo, Electrochemical synthesis of perbromate using conductivediamond anodes, Journal of Applied Electrochemistry, 40 (2010) 1715-1719.

[10] A. Sanchez-Carretero, C. Saez, P. Canizares, S. Cotillas, M.A. Rodrigo, Improvements in the Electrochemical Production of Ferrates with Conductive Diamond Anodes Using Goethite as Raw Material and Ultrasound, Industrial \& Engineering Chemistry Research, 50 (2011) 7073-7076.

[11] J.A. Lara-Ramos, C. Saez, F. Machuca-Martinez, M.A. Rodrigo, Electro-ozonizers: A new approach for an old problem, Separation and Purification Technology, 241 (2020).

[12] M.E.H. Bergmann, J. Rollin, T. Iourtchouk, The occurrence of perchlorate during drinking water electrolysis using BDD anodes, Electrochimica Acta, 54 (2009) 2102-2107.

[13] M.E.H. Bergmann, A.S. Koparal, T. Iourtchouk, Electrochemical Advanced Oxidation Processes, Formation of Halogenate and Perhalogenate Species: A Critical Review, Critical Reviews in Environmental Science and Technology, 44 (2014) 348-390.

[14] H. Bergmann, A.S. Koparal, The formation of chlorine dioxide in the electrochemical treatment of drinking water for disinfection, Electrochimica Acta, 50 (2005) 5218-5228.

[15] D.-S. Jin, B.-R. Deshwal, Y.-S. Park, H.-K. Lee, Simultaneous removal of SO2 and NO by wet scrubbing using aqueous chlorine dioxide solution, Journal of Hazardous Materials, 135 (2006) 412-417.

[16] B.R. Deshwal, H.K. Lee, Kinetics and mechanism of chloride based chlorine dioxide generation process from acidic sodium chlorate, Journal of Hazardous Materials, 108 (2004) 173-182.

[17] B.R. Deshwal, H.K. Lee, Manufacture of chlorine dioxide from sodium chlorate: State of the art, Journal of Industrial and Engineering Chemistry, 11 (2005) 330-346.

[18] B.R. Deshwal, H.K. Lee, Manufacture of chlorine dioxide from sodium chlorite: Process chemistry, Journal of Industrial and Engineering Chemistry, 11 (2005) 125-136.

[19] A. Sanchez-Carretero, C. Saez, P. Canizares, M.A. Rodrigo, Electrochemical production of perchlorates using conductive diamond electrolyses, Chemical Engineering Journal, 166 (2011) 710-714.

[20] D.C. de Moura, C.K. Costa de Araujo, C.L.P.S. Zanta, R. Salazar, C.A. Martinez-Huitle, Active chlorine species electrogenerated on $\mathrm{Ti} / \mathrm{Ru} 0.3 \mathrm{Ti} 0.7 \mathrm{O} 2$ surface: Electrochemical behavior, concentration determination and their application, Journal of Electroanalytical Chemistry, 731 (2014) 145-152.

[21] O. Azizi, D. Hubler, G. Schrader, J. Farrell, B.P. Chaplin, Mechanism of Perchlorate Formation on Boron-Doped Diamond Film Anodes, Environmental Science \& Technology, 45 (2011) 10582-10590.

[22] G.O.S. Santos, K.I.B. Eguiluz, G.R. Salazar-Banda, C. Saez, M.A. Rodrigo, Understanding the electrolytic generation of sulfate and chlorine oxidative species with different boron-doped diamond anodes, Journal of Electroanalytical Chemistry, 857 (2020).

[23] K.M. Macounova, N. Simic, E. Ahlberg, P. Krtil, Electrocatalytic Aspects of the Chlorate Process: A Voltammetric and DEMS Comparison of RuO2 and DSA Anodes, Journal of the Electrochemical Society, 165 (2018) E751-E758.

[24] E. Mostafa, P. Reinsberg, S. Garcia-Segura, H. Baltruschat, Chlorine species evolution during electrochlorination on borondoped diamond anodes: In-situ electrogeneration of Cl-2, Cl2O and ClO2, Electrochimica Acta, 281 (2018) 831-840. [25] M.E.H. Bergmann, T. Iourtchouk, W. Schmidt, J. Hartmann, M. Fischer, G. Nuesske, D. Gerngross, Laboratory- and technical-scale comparison of chlorate and perchlorate formation during drinking water electrolysis: a field study, Journal of Applied Electrochemistry, 45 (2015) 765-778.

[26] B. Endrodi, N. Simic, M. Wildlock, A. Cornell, A review of chromium(VI) use in chlorate electrolysis: Functions, challenges and suggested alternatives, Electrochimica Acta, 234 (2017) 108-122.

[27] F. Safizadeh, N. Sorour, E. Ghali, G. Houlachi, Corrosion behavior of Fe-Mo and Fe-Mo-P cathodic coatings in the simulated electrolyte for sodium chlorate production, Electrochimica Acta, 269 (2018) 340-349. 
[28] J. Wanngard, M. Wildlock, The catalyzing effect of chromate in the chlorate formation reaction, Chemical Engineering Research \& Design, 121 (2017) 438-447.

[29] S. Sorlini, F. Gialdini, M. Biasibetti, C. Collivignarelli, Influence of drinking water treatments on chlorine dioxide consumption and chlorite/chlorate formation, Water Research, 54 (2014) 44-52.

[30] H. Selcuk, M.A. Anderson, Effect of $\mathrm{pH}$, charge separation and oxygen concentration in photoelectrocatalytic systems: active chlorine production and chlorate formation, Desalination, 176 (2005) 219-227.

[31] Y.J. Jung, K.W. Baek, B.S. Oh, J.-W. Kang, An investigation of the formation of chlorate and perchlorate during electrolysis using Pt/Ti electrodes: The effects of $\mathrm{pH}$ and reactive oxygen species and the results of kinetic studies, Water Research, 44 (2010) 5345-5355.

[32] A.M. Polcaro, A. Vacca, M. Mascia, S. Palmas, J.R. Ruiz, Electrochemical treatment of waters with BDD anodes: kinetics of the reactions involving chlorides, Journal of Applied Electrochemistry, 39 (2009) 2083-2092.

[33] J.F. Perez, C. Saez, J. Llanos, P. Canizares, C. Lopez, M.A. Rodrigo, Improving the Efficiency of Carbon Cloth for the Electrogeneration of $\mathrm{H} 2 \mathrm{O} 2$ : Role of Polytetrafluoroethylene and Carbon Black Loading, Industrial \& Engineering Chemistry Research, 56 (2017) 12588-12595.

[34] J.F. Perez, A. Galia, M.A. Rodrigo, J. Llanos, S. Sabatino, C. Saez, B. Schiavo, O. Scialdone, Effect of pressure on the electrochemical generation of hydrogen peroxide in undivided cells on carbon felt electrodes, Electrochimica Acta, 248 (2017) 169-177.

[35] J.F. Perez, J. Llanos, C. Saez, C. Lopez, P. Canizares, M.A. Rodrigo, The jet aerator as oxygen supplier for the electrochemical generation of $\mathrm{H} 2 \mathrm{O} 2$, Electrochimica Acta, 246 (2017) 466-474.

[36] J.F. Perez, J. Llanos, C. Saez, C. Lopez, P. Canizares, M.A. Rodrigo, The pressurized jet aerator: A new aeration system for high-performance H2O2 electrolyzers, Electrochemistry Communications, 89 (2018) 19-22.

[37] J.F. Perez, J. Llanos, C. Saez, C. Lopez, P. Canizares, M.A. Rodrigo, A microfluidic flow-through electrochemical reactor for wastewater treatment: A proof-of-concept, Electrochemistry Communications, 82 (2017) 85-88.

[38] V.S. Pinheiro, E.C. Paz, L.R. Aveiro, L.S. Parreira, F.M. Souza, P.H.C. Camargo, M.C. Santos, Ceria high aspect ratio nanostructures supported on carbon for hydrogen peroxide electrogeneration, Electrochimica Acta, 259 (2018) 865-872. [39] H. He, B. Jiang, J. Yuan, Y. Liu, X. Bi, S. Xin, Cost-effective electrogeneration of H2O2 utilizing HNO3 modified graphite/polytetrafluoroethylene cathode with exterior hydrophobic film, Journal of Colloid and Interface Science, 533 (2019) 471-480.

[40] W. Zhou, L. Rajic, X. Meng, R. Nazari, Y. Zhao, Y. Wang, J. Gao, Y. Qin, A.N. Alshawabkeh, Efficient H2O2 electrogeneration at graphite felt modified via electrode polarity reversal: Utilization for organic pollutants degradation, Chemical Engineering Journal, 364 (2019) 428-439.

[41] J.F. Perez, J. Llanos, C. Saez, C. Lopez, P. Canizares, M.A. Rodrigo, Electrochemical jet-cell for the in-situ generation of hydrogen peroxide, Electrochemistry Communications, 71 (2016) 65-68.

[42] Y. Sheng, Y. Zhao, X. Wang, R. Wang, T. Tang, Electrogeneration of H2O2 on a composite acetylene black-PTFE cathode consisting of a sheet active core and a dampproof coating, Electrochimica Acta, 133 (2014) 414-421.

[43] L. Li, H. Hu, X. Teng, Y. Yu, Y. Zhu, X. Su, Electrogeneration of $\mathrm{H} 2 \mathrm{O} 2$ using a porous hydrophobic acetylene black cathode for electro-Fenton process, Chemical Engineering and Processing-Process Intensification, 133 (2018) 34-39.

[44] R. Babaei-Sati, J.B. Parsa, Electrogeneration of $\mathrm{H} 2 \mathrm{O} 2$ using graphite cathode modified with electrochemically synthesized polypyrrole/MWCNT nanocomposite for electro-Fenton process, Journal of Industrial and Engineering Chemistry, 52 (2017) 270276.

[45] L. Zhou, Z. Hu, C. Zhang, Z. Bi, T. Jin, M. Zhou, Electrogeneration of hydrogen peroxide for electro-Fenton system by oxygen reduction using chemically modified graphite felt cathode, Separation and Purification Technology, 111 (2013) $131-136$.

[46] G. Xia, Y. Lu, H. Xu, Electrogeneration of hydrogen peroxide for electro-Fenton via oxygen reduction using polyacrylonitrile-based carbon fiber brush cathode, Electrochimica Acta, 158 (2015) 390-396.

[47] Y. Sheng, S. Song, X. Wang, L. Song, C. Wang, H. Sun, X. Niu, Electrogeneration of hydrogen peroxide on a novel highly effective acetylene black-PTFE cathode with PTFE film, Electrochimica Acta, 56 (2011) 8651-8656.

[48] E.C. Paz, L.R. Aveiro, V.S. Pinheiro, F.M. Souz, V.B. Lima, F.L. Silva, P. Hammer, M.R.V. Lanza, M.C. Santos, Evaluation of $\mathrm{H} 2 \mathrm{O} 2$ electrogeneration and decolorization of Orange II azo dye using tungsten oxide nanoparticle-modified carbon, Applied Catalysis B-Environmental, 232 (2018) 436-445.

[49] J.F. Carneiro, R.S. Rocha, P. Hammer, R. Bertazzoli, M.R.V. Lanza, Hydrogen peroxide electrogeneration in gas diffusion electrode nanostructured with Ta2O5, Applied Catalysis a-General, 517 (2016) 161-167.

[50] C. Ridruejo, F. Alcaide, G. Alvarez, E. Brillas, I. Sires, On-site H2O2 electrogeneration at a CoS2-based air-diffusion cathode for the electrochemical degradation of organic pollutants, Journal of Electroanalytical Chemistry, 808 (2018) 364-371.

[51] Y. Wang, W. Zhou, J. Gao, Y. Ding, K. Kou, Oxidative modification of graphite felts for efficient H2O2 electrogeneration: Enhancement mechanism and long-term stability, Journal of Electroanalytical Chemistry, 833 (2019) 258-268.

[52] Y. Qian, Y. Chen, Y. Jiang, L. Zhang, A clean production process of sodium chlorite from sodium chlorate, Journal of Cleaner Production, 15 (2007) 920-926.

[53] M.F. Hoq, B. Indu, W.R. Ernst, L.T. Gelbaum, OXIDATION-PRODUCTS OF METHANOL IN CHLORINE DIOXIDE PRODUCTION, Industrial \& Engineering Chemistry Research, 31 (1992) 1807-1810.

[54] J.P. Wood, G.B. Martin, Development and field testing of a mobile chlorine dioxide generation system for the decontamination of buildings contaminated with Bacillus anthracis, Journal of Hazardous Materials, 164 (2009) 1460-1467.

[55] H. Kim, Y. Kang, L.R. Beuchat, J.-H. Ryu, Production and stability of chlorine dioxide in organic acid solutions as affected by $\mathrm{pH}$, type of acid, and concentration of sodium chlorite, and its effectiveness in inactivating Bacillus cereus spores, Food Microbiology, 25 (2008) 964-969. 
[56] 이정민, 이남택, 류지훈, Effect of various environmental factors such as concentration of $\mathrm{NaClO} 2$, relative humidity, temperature, and time on the production of gaseous chlorine dioxide, Korean Journal of Food Science and Technology, 51 (2019) 404-409.

[57] G. Yin, Y. Ni, Using hydrogen peroxide in a methanol-based chlorine dioxide generation process, Industrial \& Engineering Chemistry Research, 38 (1999) 3319-3323.

[58] G.H. Yin, Y.H. Ni, Mechanism of the $\mathrm{ClO} 2$ generation from the $\mathrm{H} 2 \mathrm{O} 2-\mathrm{HClO} 3$ reaction, Canadian Journal of Chemical Engineering, 78 (2000) 827-833.

[59] M. Burke, J. Tenney, B. Indu, M.F. Hoq, S. Carr, W.R. Ernst, KINETICS OF HYDROGEN-PEROXIDE CHLORATE REACTION IN THE FORMATION OF CHLORINE DIOXIDE, Industrial \& Engineering Chemistry Research, 32 (1993) 14491456

[60] B. Crump, W.R. Ernst, H.M. Neumann, Influence of $\mathrm{H} 2 \mathrm{O} 2$ on a chloride-dependent reaction path to chlorine dioxide, Aiche Journal, 44 (1998) 2494-2500

[61] G. Yin, Y. Ni, The effect of chloride on the $\mathrm{HClO} 2-\mathrm{HOCl} 2$ reaction in a $4.5 \mathrm{~mol} / \mathrm{L}$ sulfuric acid solution, Canadian Journal of Chemical Engineering, 76 (1998) 248-252.

[62] K.C. Pillai, T.O. Kwon, B.B. Park, I.S. Moon, Studies on process parameters for chlorine dioxide production using $\mathrm{IrO} 2$ anode in an un-divided electrochemical cell, Journal of Hazardous Materials, 164 (2009) 812-819.

[63] Y.-T. Tsai, Y.-H. Hsieh, C.-L. Yang, C.-Y. Chang, S.-H. You, Using membrane electrolysis method to generate chlorine dioxide, in: International Conference on Environment Science and Engineering (ICESE), Bali, INDONESIA, 2011, pp. 33-36. [64] K.C. Pillai, T.O. Kwon, B.B. Park, I.S. Moon, Using RuO2 anode for chlorine dioxide production in an un-divided electrochemical cell, Water Science and Technology, 61 (2010) 2151-2160.

[65] C.-T. Wu, C.-Y. Chang, Y.-Y. Li, Y.-L. Kuan, P.-H. Lin, An efficiency analysis for the production of chlorine dioxide by the electrolysis of brine in seawater desalination plants, Water Quality Research Journal of Canada, 54 (2019) 127-133.

[66] RISTO R, PIRJO V. Production of chlorine dioxide release material.pdf [Internet]. 2574598; 2013. Available from: 11183505 30.09.2011 E

[67] PELIN KHT, BJÖRKMAN NT. Proceso para la producción de dióxido de cloro. 2015; Available from: 187417 P 16.06.2009 US

[68] BASO FRANCESCO. Process and combined plant of production of chlorine dioxide for water treatment through desinfection [Internet]. 2014. Available from: 2012000404 28.12.2012 IT

[69] D. ANDREAS, D. HANS-JUERGEN KH. Method for producing chlorine dioxide [Internet]. 2010. Available from: $200800042011.03 .2008 \mathrm{DE}$

[70] SHIGEO A, KOICHI N, KOUICHI T, DAISUKE K. Chlorine dioxide production device and chlorine dioxide production method [Internet]. 2016. Available from: 2014072910 01.09.2014 JP 